\title{
Impacts and Challenges of Advanced Diagnostic Assays for Transplant Infectious Diseases
}

\author{
N. Esther Babady, Yeon Joo Lee, Genovefa Papanicolaou, \\ and Yi-Wei Tang
}

\section{Introduction}

The administration of immunosuppressive therapy to prevent rejection of allografts and graft-versus-host disease, although necessary, renders transplant recipients susceptible to opportunistic infections [1,2]. As a group, transplant patients present a real challenge for initial diagnosis of infection partly due to lowered or absent markers of inflammation [2]. Traditionally, these infections have been diagnosed using bacterial, fungal, and viral culture as well as a variety of immunological assays. These methods still remain the standard of care for diagnosis of most infections. However, a series of advanced detection techniques led by nucleic acid amplification have now become prominent in most clinical microbiology laboratories, and novel proteomic assays are

\section{N. E. Babady}

Department of Laboratory Medicine, Clinical Microbiology

Service, Memorial Sloan Kettering Cancer Center,

New York, NY, USA

\section{Y. J. Lee}

Department of Internal Medicine, Infectious Diseases Service, Memorial Sloan Kettering Cancer Center, New York, NY, USA

Weill Cornell Medical College, Cornell University,

New York, NY, USA

e-mail: leey1@mskcc.org

G. Papanicolaou

Department of Internal Medicine, Infectious Diseases Service,

Memorial Sloan Kettering Cancer Center, New York, NY, USA

Weill Cornell Medical College, Cornell University,

New York, NY, USA

e-mail: papanicg@mskcc.org

Y.-W. Tang $(\bowtie)$

Department of Laboratory Medicine, Clinical Microbiology

Service, Memorial Sloan-Kettering Cancer Center,

New York, NY, USA

Weill Cornell Medical College, Cornell University,

New York, NY, USA

e-mail: tangy@mskcc.org currently being added in the list of diagnostic tools available for infectious pathogen detection and identification.

The goal of this chapter is to review traditional and molecular methods used for the diagnosis of infectious diseases in transplants patients and discuss novel methodologies currently in development and their potential impact on clinical decisions.

\section{Traditional Diagnostic Assays}

\section{Culture-Based Assays}

Culture remains the gold standard for the diagnosis of most infectious diseases including those caused by bacteria, mycobacteria, and fungi $[3,4]$. One of the advantages of culture is that it does not require a priori knowledge of the specific pathogen responsible for the infection as it casts a wide search net by using multiple growth media and incubation conditions. For example, diarrhea and vomiting are common symptoms in transplant patients, and determining the infectious cause for those symptoms can be challenging due to confounding factors such as intestinal graft-versus-host diseases (GVHD) in hematopoietic stem cell transplantation (HSCT) recipients, neutropenic enterocolitis, and immunosuppressive drugs [5]. A request for a bacterial stool culture will allow detection of the most common cause of bacterial gastroenteritis, namely, Salmonella species, Shigella species, Campylobacter species, and E. coli $\mathrm{O} 157$ with a recovery rate ranging from $0.2 \%$ to $2.4 \%$ [3, 6-8]. In addition, any other bacterial organisms growing on the culture media, with potential for causing gastrointestinal symptoms, will be detected and reported. However, culture of certain organisms, including $C$. difficile, the most common cause of bacterial diarrhea in hospitalized patients, requires special culture media and setup and has been replaced in most part by nonculture-based methods. Similarly, viral causes of diarrhea including cytomegalovirus (CMV), norovirus, adenovirus, rotavirus, and other small round viruses are better detected 
by nucleic acid amplification tests (NAAT) and antigen tests [9-11].

The diagnostic yield of culture for various specimen types remains low. In one retrospective study, the yield of bronchoalveolar lavage (BAL) fluid culture for diagnosis of pneumonia in bone marrow transplant patients was reported at $2.2 \%, 3.0 \%$, and $16.4 \%$ for bacteria, fungi, and viruses, respectively [4]. In contrast, the use of PCR tests and antigen testing increased the overall diagnostic yield to $22 \%$, although the increased detection of CMV by PCR was not deemed clinically significance for all cases. The diagnostic yield of BAL in other studies was higher with one study reporting rates of $31 \%, 12.7 \%$, and $23.6 \%$ for detection of bacteria, fungi, and viruses, respectively, in cancer patients [12]. For solid organ transplants (SOT), the overall recovery of pathogens by culture can be higher, up to $58.9 \%$ in lung transplants [13-15].

Blood culture is important for diagnosis of bacteremia and fungemia [16]. Unfortunately, the yield of blood culture remains low for both conditions [17-20]. Current blood culture systems are automated and set up to continuously monitor blood culture for the detection of microorganisms. An exception to continuous monitoring is the use of the isolator tube system, a manual lysis-centrifugation system (Wampole Laboratories, Cranbury, NJ). Performance of the isolator tube has been evaluated extensively against other automated blood culture systems designed to improve recovery of fungi such as the MYCO/F Lytic bottle (BD Diagnostics, Sparks, MD) with some studies showing increased recovery of $H$. capsulatum and $C$. neoformans [21, 22], while other concludes that the two systems performed equally well [23, 24]. A study by Creger et al. retrospectively analyzed the performance of the isolator tube system specifically in a cancer population and did not observed an advantage over conventional blood culture methods [25]. Even with the use of the isolator tube, the detection of fungi in blood culture is low, and in biopsy-proven candidiasis, only $50 \%$ of patients had a positive blood culture [26].

In transplant patients, the yield of blood culture varies with the type of transplant and the degree of immunosuppression. In lung transplant patients, the yield of blood culture can be as high as $25 \%$ with $S$. aureus, $P$. aeruginosa, and Candida species being the most common isolates recovered $[27,28]$, while in HSCT, the yield varies greatly from $4.9 \%$ to $8.7 \%$ and is dominated by Gram-positive bacteria [29-32].

The majority of fungal isolates from blood culture are Candida species, with $C$. albicans being the most common species isolated [18]. Although rare, other non-Candida yeasts including Trichosporon species, Rhodotorula species, and Saccharomyces cerevisiae are being recovered with increased frequency from blood cultures of immunocompromised patients [33, 34]. Fungemia caused by molds, including Aspergillus species, is rarely detected by blood culture
[35-37]. In patients with indwelling devices, molds such as Fusarium, Paecilomyces, Scedosporium, and Wangiella have been recovered from blood culture [38-40].

A recent study by Limmathurotsakul et al. highlighted the limitation of culture as a diagnostic tools and an imperfect gold standard [41]. The authors applied Bayesian latent class models (LCM) to establish the true sensitivity of culture and the true specificity of four serological tests for detection of pathogens using Burkholderia pseudomallei and melioidosis as a model system. Using Bayesian LCM with either conditional independence (i.e., no single test considered gold standard and no correlation among tests) or conditional dependence (i.e., correlation among all tests), the sensitivity of culture was estimated to be $61 \%$ with a negative predictive value of $62.1 \%$ [41]. The specificity and positive predictive value of the four serological tests increased significantly using both Bayesian LCM models, emphasizing the limitation of using the culture as an imperfect gold standard.

Recent studies defining microbial populations of various organs using deep sequencing and high-density sequencing methods have now revealed the complexity of microbial organisms, many of them non-culturable, present in various tissues and the difference in composition for transplants versus healthy patients [42, 43]. The significance of detecting these non-culturable organisms for infectious diseases management remains to be established.

\section{Antigens and Antibody Assays}

Depending on the degree and type of immunosuppression, transplant patients may not be able to mount a sufficient antibody response to pathogens limiting the use of serological assays to detect antibodies [2]. On the other hand, antigen testing can be beneficial, especially for fungal infections where results of these tests are used as one of the mycological criteria to define invasive fungal disease (IFD) [44]. Some of the most commonly used antigen tests include the galactomannan (GM) antigen produced by members of the Aspergillus family and the (1,3) $\beta$-D (BD) glucans, present in the cell wall of Aspergillus and a variety of other molds and yeasts [45].

The serum GM assay (Platelia Aspergillus EIA, BioRad Laboratories) was approved by the United States Food and Drugs Administration (FDA) in 2003. The assay is an enzyme immunoassay that uses rat monoclonal antibody EBA-2 to detect circulating GM antigen in serum. The GM assay has been evaluated extensively in various patient populations with sensitivity ranging from $30 \%$ to $100 \%$ and specificity ranging from $38 \%$ to $98 \%$ in serum with greater utility in HSCT patients than in SOT recipients [46]. In a study by Jathavedam and colleagues, the GM assay was shown to have limited utility within the first 100 days after auto-SCT 
and therefore not useful for patient management decision [47]. In another study conducted in patients with hematologic malignancies, the sensitivity of the GM assay was $49 \%$ for invasive fungal infections caused by Aspergillus species other than A. fumigatus and only $13 \%$ for IFD caused by $A$. fumigatus [48]. Results of these various studies suggested that the performance of the GM assay depends on several factors including the infecting species of Aspergillus, the type of transplant populations, the frequency of testing, and the duration of antifungal therapy $[45,49]$. The sensitivity of the GM assay in BAL of HSCT recipients and patients with hematological malignancies is higher than that reported for serum and ranges between $88 \%$ and $100 \%$ using the same optical density cutoff value used for serum [45, 50, 51]. In solid-organ transplant patients, the sensitivity and specificity of the GM assay in BAL ranged from $60 \%$ to $100 \%$ and 84-98\%, respectively, depending on the optical density cutoff value used [50, 52-56]. Thus, the GM assay in BAL is a useful additional test for diagnosing IFD. False-positive results were observed in patients receiving piperacillin, amoxicillin, or ticarcillin with or without a beta-lactamase inhibitor, in patients being administered electrolyte replacement fluids (i.e., PlasmaLyte), and in patients infected with molds other than Aspergillus for a low specificity and positive predictive value $[45,57]$. However, a study by Vergidis et al. showed that the current formulation of piperacillin-tazobactam do not appear to be contaminated with galactomannan [58].

Four assays, the Fungitell (Associates of Cape Cod Inc., East Falmouth, MA, cutoff, 60-80 pg/mL), the Fungitec-G (Seikagaku, Tokyo, Japan, cutoff, $20 \mathrm{pg} / \mathrm{mL}$ ), the Wako (Wako Pure Chemical Industries, Tokyo, Japan, cutoff, 11 pg/ $\mathrm{mL}$ ), and Maruha (Maruha-Nichiro Foods, Tokyo, Japan, cutoff, $11 \mathrm{pg} / \mathrm{mL}$ ) are commercially available for the detection of $(1,3)-\beta-D$ (BD) glucans, a cell wall antigen found in most fungal species cell wall excluding Mucormycetes and Cryptococcus species [59]. A recent meta-analysis review of studies conducted in adult hemato-oncology patients showed similar performance for all four assays in the diagnosis of IFD, a higher diagnostic yield for performance of two consecutive tests, and an overall low sensitivity (52\%) and high specificity (99\%) for proven or probable IFD [59]. In another meta-analysis study, which included reports with various patient populations, the sensitivity and specificity of the BD glucans test were $77 \%$ and $85 \%$, respectively [60]. Both studies concluded that the BD glucans assay was a useful adjunct test, especially for diagnosis of IFD due to Candida and Aspergillus. However, a recent report of high-false positive in patients with hematologic malignancies puts in question the value of this test as a stand-alone test for diagnosis of IFD [61].

The sensitivity of BD glucans is highest (90-100\%) for the diagnosis of Pneumocystis jirovecii pneumonia (PCP), although its specificity in non-HIV immunocompromised patients varies widely (42-98\%); therefore, results of the test taken alone are not conclusive for making a diagnosis of PCP $[62,63]$. However, studies have shown that serum BD glucan levels correlate well with $P$. jirovecii fungal load in BAL as determined by Pneumocystis PCR, supporting the use of the assay to monitor response to therapy [62, 63].

Other useful antigens tests used for diagnosis of fungal infections include the latex agglutination cryptococcal antigen, which has higher sensitivity for central nervous system infection than disseminated disease, and the urine and serum antigen for endemic mycoses (Blastomyces dermatitidis and Histoplasma capsulatum antigens), although some crossreaction occurs among targets [64].

The diagnosis of viral infections has been replaced in most instances by nucleic acid-based tests. Antigens testing and serological assays by methods such as direct fluorescent antibody (DFA) staining and enzyme immunoassays (EIA) do still play a part in the diagnosis of certain infections including diagnosis of acute or chronic hepatitis, infectious mononucleosis, and HTLV-1-/HTLV2-associated T-cell leukemia [65]. One of the most common viral antigens tested in transplant patients is the CMV pp65 antigen for monitoring of viral loads [66]. The reported sensitivity and specificity of the CMV antigenemia test varies greatly due to lack of standardization in protocols including specimen processing, monoclonal antibody used, slide processing, and quantification [67]. Advantages of the antigenemia assay include its low cost in terms of reagents and equipment, but due to its disadvantages including the need for rapid specimen processing, the labor-intensive nature of the assay, and the subjectivity in reading of the slides, the antigenemia test has been replaced in many institutions by molecular tests for monitoring of CMV viral loads [67-69].

Bacterial antigen tests of importance for transplant patients include the urinary antigen tests for Legionella pneumophila serotype 1 (Binax, Scarborough, Maine, USA) and Streptococcus pneumoniae (Binax, Scarborough, Maine, USA), which are rapid, noninvasive tests useful in the diagnosis of both community- and hospital-acquired pneumonia $[70,71]$.

\section{New Generation Diagnostic Assays}

Although the use of culture and serological assays provides important information, their shortcomings created a need to develop faster and more sensitive assays. The following sections will cover the more rapid methods currently in use in most laboratories for diagnosis of infection and the newer methods being developed and conclude with the impact of these methods on the diagnosis and management of transplant patients. 


\section{Genomic Assays}

The first published polymerase chain reaction (PCR) report described the amplification of specific target sequences of the $\beta$-globin gene for diagnosis of sickle cell anemia [72, 73]. Several modifications and improvements have occurred since that first report, ultimately resulting in the transfer of PCR from research laboratories to clinical diagnostic laboratories [74, 75]. Alternative nucleic acid amplification formats have since been developed including ligase chain reaction (LCR), nucleic acid sequence-based amplification (NASBA), branched DNA (b-DNA) signal amplification, strand displacement amplification (SDA), helicase-dependent amplification (HDA), and loop-mediated amplification (LAMP) [76, 77]. Numerous commercial molecular assays have been approved by DFA for diagnosis of microbial infections in transplant patients (Table 47.1).

The development of real-time PCR, combining rapid thermal cycling and real-time monitoring of amplification

Table 47.1 List of US FDA-cleared commercial molecular tests

\begin{tabular}{|c|c|c|c|}
\hline Manufacturer & Test name & Targets & $\begin{array}{l}\text { Complexity } \\
\text { level }\end{array}$ \\
\hline \multirow{3}{*}{ BD diagnostics } & BD MAX MRSA assay & MDRO surveillance & $\sqrt{ }$ \\
\hline & BD GeneOhm MRSA ACP assay & MDRO surveillance & $\sqrt{ }$ \\
\hline & BD GeneOhm StaphSR assay & Bacteremia & $\sqrt{ }$ \\
\hline \multirow[t]{2}{*}{ bioMérieux } & BioFire FilmArray blood culture identification panel & Bacteremia & $\sqrt{ }$ \\
\hline & NucleiSENS EasyQ MRSA assay & MDRO surveillance & $\sqrt{ }$ \\
\hline \multirow[t]{4}{*}{ Cepheid } & Xpert MRSA & MDRO surveillance & $\sqrt{ }$ \\
\hline & Xpert SA nasal complete & MDRO surveillance & $\sqrt{ }$ \\
\hline & Xpert MRSA/SA SSTI & $\begin{array}{l}\text { Skin and soft tissue } \\
\text { infections }\end{array}$ & $\sqrt{ }$ \\
\hline & Xpert MRSA/SA BC & Bacteremia & $\sqrt{ }$ \\
\hline Nanosphere, Inc. & Verigene gram-positive blood culture test & Bacteremia & $\sqrt{ }$ \\
\hline Roche molecular diagnostics & LightCycler MRSA advanced test & MDRO surveillance & $\sqrt{ }$ \\
\hline \multirow[t]{2}{*}{ AdvanDx, Inc. } & E. faecalis/OE PNA FISH & Bacteremia & \\
\hline & E. faecalis PNA FISH & Bacteremia & \\
\hline BD diagnostics & BD GeneOhm VanR assay & MDRO surveillance & $\sqrt{ }$ \\
\hline bioMérieux/BioFire & BioFire FilmArray blood culture identification panel & Bacteremia & $\sqrt{ }$ \\
\hline Cepheid & Xpert vanA & MDRO surveillance & $\sqrt{ }$ \\
\hline Intelligent medical devices, Inc. & IMDx VanR for Abbott m200 & MDRO surveillance & $\sqrt{ }$ \\
\hline Nanosphere, Inc. & Verigene gram-positive blood culture test & Bacteremia & $\sqrt{ }$ \\
\hline \multirow[t]{2}{*}{ BD diagnostics } & BD MAX C. diff assay & C. difficile infection & \\
\hline & BD GeneOhm C. diff assay & C. difficile infection & \\
\hline bioMérieux/BioFire & FilmArray gastrointestinal panel & $\begin{array}{l}\text { Gastrointestinal tract } \\
\text { infection }\end{array}$ & \\
\hline \multirow[t]{2}{*}{ Cepheid } & Xpert $C$. difficile & C. difficile infection & \\
\hline & Xpert $C$. difficile/epi & C. difficile infection & \\
\hline Focus diagnostics, Inc. & Simplexa $C$. difficile universal direct assay & C. difficile infection & \\
\hline Great Basin scientific, Inc. & Portrait Toxigenic $C$. difficile assay & C. difficile infection & \\
\hline Intelligent medical devices, Inc. & IMDx C. difficile for Abbott m200 & C. difficile infection & \\
\hline $\begin{array}{l}\text { Luminex molecular diagnostics, } \\
\text { Inc. }\end{array}$ & xTAG gastrointestinal pathogen panel (GPP) & $\begin{array}{l}\text { Gastrointestinal tract } \\
\text { infection }\end{array}$ & \\
\hline Meridian biosciences, Inc. & Illumigene $C$. difficile DNA amplification & C. difficile infection & \\
\hline Nanosphere, Inc. & Verigene $C$. difficile test & C. difficile infection & \\
\hline PrimeraDx & ICEPlex C. difficile kit & C. difficile infection & \\
\hline Prodesse, Inc. & ProGastro $\mathrm{Cd}$ assay & C. difficile infection & \\
\hline Quidel Corp. & Quidel molecular Direct $C$. difficile assay & C. difficile infection & \\
\hline \multirow{4}{*}{ AdvanDx, Inc. } & GNR traffic light PNA FISH & Bacteremia & $\sqrt{ }$ \\
\hline & E. coli/P. aeruginosa PNA FISH & Bacteremia & \\
\hline & EK/P. aeruginosa PNA FISH & Bacteremia & \\
\hline & E. coli PNA FISH & Bacteremia & \\
\hline bioMérieux & BioFire FilmArray blood culture identification panel & Bacteremia & $\sqrt{ }$ \\
\hline Nanosphere, Inc. & Verigene gram-negative blood culture test & Bacteremia & $\sqrt{ }$ \\
\hline \multirow{2}{*}{ AdvanDx, Inc. } & C. albicans PNA FISH & Bacteremia & $\sqrt{ }$ \\
\hline & C. albicans/C. glabrata PNA FISH & Bacteremia & \\
\hline
\end{tabular}


Table 47.1 (continued)

\begin{tabular}{|c|c|c|c|}
\hline Manufacturer & Test name & Targets & $\begin{array}{l}\text { Complexity } \\
\text { level }\end{array}$ \\
\hline & Yeast traffic light PNA FISH & Bacteremia & \\
\hline bioMérieux & BioFire FilmArray blood culture identification panel & Bacteremia & \\
\hline Alere Scarborough, Inc. & Alere I influenza A and B & Pneumonia & \\
\hline bioMérieux/BioFire & FilmArray respiratory panel & Pneumonia & \\
\hline \multirow[t]{2}{*}{ Cepheid } & Xpert flu/RSV & Pneumonia & $\sqrt{ }$ \\
\hline & Xpert flu & Pneumonia & \\
\hline \multirow[t]{2}{*}{ Focus diagnostics, Inc. } & Simplexa flu A/B \& RSV & Pneumonia & \\
\hline & Simplexa influenza A H1N1 & Pneumonia & \\
\hline GenMark diagnostics, Inc. & eSensor respiratory viral panel & Pneumonia & \\
\hline Intelligent medical devices, Inc. & IMDx flu $\mathrm{A} / \mathrm{B}$ and RSV for Abbott m 200 & Pneumonia & \\
\hline IQuum/Roche molecular Inc. & Liat influenza $\mathrm{A} / \mathrm{B}$ assay & Pneumonia & \\
\hline \multirow{2}{*}{$\begin{array}{l}\text { Luminex molecular diagnostics, } \\
\text { Inc. }\end{array}$} & xTAG respiratory viral panel (RVP) & Pneumonia & \\
\hline & xTAG respiratory viral panel FAST (RVP FAST) & Pneumonia & \\
\hline Meridian biosciences, Inc. & Illumigene mycoplasma DNA amplification & Pneumonia & \\
\hline \multirow[t]{2}{*}{ Nanosphere, Inc. } & Verigene respiratory virus + test & Pneumonia & \\
\hline & $\begin{array}{l}\text { Verigene respiratory pathogens flex nucleic acid test (RP } \\
\text { flex) }\end{array}$ & Pneumonia & \\
\hline \multirow[t]{4}{*}{ Prodesse, Inc. } & Pro hMPV assay & Pneumonia & \\
\hline & ProFAST assay & Pneumonia & \\
\hline & ProParaflu assay & Pneumonia & \\
\hline & ProFlu+ assay & Pneumonia & $\sqrt{ }$ \\
\hline QIAGEN GmbH & Artus Infl A/B RG RT-PCR kit & Pneumonia & \\
\hline \multirow[t]{3}{*}{ Quidel Corp. } & Quidel molecular RSV + hMPV assay & Pneumonia & \\
\hline & Quidel molecular hMPV assay & Pneumonia & \\
\hline & Quidel molecular influenza A + B assay & Pneumonia & \\
\hline BD diagnostics & BD MAX enteric parasite panel & & \\
\hline BD diagnostics & BD MAX enteric bacterial panel & & \\
\hline bioMérieux & BioFire FilmArray gastrointestinal panel & $\begin{array}{l}\text { Gastrointestinal tract } \\
\text { infection }\end{array}$ & \\
\hline Cepheid & Xpert norovirus & $\begin{array}{l}\text { Gastrointestinal tract } \\
\text { infection }\end{array}$ & \\
\hline $\begin{array}{l}\text { Luminex molecular diagnostics, } \\
\text { Inc. }\end{array}$ & xTAG gastrointestinal pathogen panel (GPP) & $\begin{array}{l}\text { Gastrointestinal tract } \\
\text { infection }\end{array}$ & \\
\hline $\begin{array}{l}\text { Luminex molecular diagnostics, } \\
\text { Inc. }\end{array}$ & xTAG gastrointestinal pathogen panel (GPP) & $\begin{array}{l}\text { Gastrointestinal tract } \\
\text { infection }\end{array}$ & \\
\hline Prodesse, Inc. & ProGastro SSCS assay & $\begin{array}{l}\text { Gastrointestinal tract } \\
\text { infection }\end{array}$ & \\
\hline Prodesse, Inc. & ProAdeno+ assay & $\begin{array}{l}\text { Gastrointestinal tract } \\
\text { infection }\end{array}$ & \\
\hline Nanosphere, Inc. & Verigene enteric test & $\begin{array}{l}\text { Gastrointestinal tract } \\
\text { infection }\end{array}$ & \\
\hline
\end{tabular}

products $[78,79]$, completely revolutionized the practice of clinical microbiology $[80,81]$. Today, real-time nucleic acid amplification methods are mainstream in most sections of clinical microbiology, and their impact on care of transplant patients is significant.

Several real-time PCR laboratory-developed tests (LDT) as well as a few FDA-approved assays are used for the diagnosis of bacterial infections in transplant patients. Bacteria targeted for assays development have traditionally been those related to nosocomial infections. For example, until recently, most PCR assays for detection of $C$. difficile were LDT assays that resulted in an increased sensitivity and turnaround time for results [82-85]. At the time of this chapter preparation, the FDA had cleared over eight molecular assays for the diagnosis of Clostridium difficile infection (CDI). Similarly, rapid molecular assays have been developed for a variety of bacterial targets including difficult-to-culture or slow-growing organisms (i.e., Mycoplasma pneumoniae, Chlamydophila pneumoniae, Borrelia burgdorferi), targeted diagnosis (i.e., group A Streptococcus in throat swabs), and nosocomial pathogens (methicillin-resistant $S$. aureus, methicillin-sensitive $S$. aureus, and vancomycin-resistant Enterococci) [80]. 
The turnaround time and identification of the most common Mycobacteria species were greatly improved with the introduction of nucleic acid hybridization probes in the laboratory. Nucleic acid hybridization probes are single-stranded or double-stranded DNA/RNA fragments complementary to a sequence in the target organisms and most commonly labeled with a fluorescent or chemiluminescent marker for detection [86]. Probes for same-day identification of $M$. tuberculosis complex, M. kansasii, M. avium complex, and M. gordonae from either solid or liquid cultures have been commercially available since the early 1990s (Gen-Probes, San Diego, CA). These probes show excellent sensitivity and specificity, although cross-reaction has been reported between $M$. tuberculosis complex and M. terrae [87-90]. Similar probes are available for identification of medically important filament fungal species.

The current trend for molecular diagnosis is a move toward syndromic, highly multiplexed real-time PCR assays and newer technologies including various solid and liquid microarray formats. Currently, FDA-cleared molecular syndromic panels are available for the diagnosis of respiratory tract infections, bloodstream infections, gastrointestinal infections, and meningitis/encephalitis (Table 47.2). These panels differ on the numbers of pathogens they can detect (5-27 targets), the type of pathogens included (e.g., bacteria, viruses, or yeasts), the level of complexity (low versus high), and the turnaround time to results (from $1 \mathrm{~h}$ to $12 \mathrm{~h}$ ). Performance characteristics, however, are comparable with sensitivity and specificity greater than $90 \%$ when compared to culture or bi-directional sequencing as the gold standard [91].

Other multiplexed bacterial assays are available outside of the United States, for example, the LightCycler SeptiFast (Roche Diagnostics GmbH, Wien/Austria), a multiplexed real-time PCR-based assay that can detect bacteria and yeasts directly from whole blood. An agreement of up to $83 \%$ between SeptiFast and blood culture results has been reported with the overall conclusion that in its cur- rent form, the assay can be used to supplement rather than replace blood culture methods [92-94]. The SeptiFast assay has been shown to be especially useful in providing additional information for immunocompromised patients including liver transplants, septic ICU patients, and neutropenic patients, for fungal infection and in cases of prior antibiotic administration [93-96].

Other potential molecular methods have been developed and evaluated for the diagnosis of bacterial infections including sequencing [97], quantitative loop-mediated isothermal amplification [98], PCR hybridization [99], and mass spectrometry [100].

As described in the previous section, the diagnosis of IFD currently relies on microscopic examination, recovery of molds or yeasts in culture, detection of fungal antigens including galactomannan and BD glucans, and various radiological findings of pulmonary infiltrates [45, 101]. Although useful, these methods can lack specificity, be time-consuming, or result in inconclusive findings. A study by Lin et al. [102] suggested that earlier diagnosis of fungal infection could result in decreased mortality in neutropenic and cancer patients. Molecular diagnosis of fungal infections has relied mostly on the identification of organisms growing in culture. Nucleic acid hybridization probes for identification of Blastomyces dermatitidis, Histoplasma capsulatum, and Coccidioides immitis from culture isolates have been available since the early 1990s (AccuProbes, Gen-Probe, San Diego, CA) with sensitivity ranging from 87.8 to $100 \%$ and specificity nearing $100 \%$ [103, 104]. The hybridization probes are rapid and demonstrate good sensitivity and specificity from culture, although some cross-reactivity with uncommon fungal organisms has been reported [104, 105]. More recently, peptide nucleic acid fluorescent in situ hybridization (PNA FISH) probes and syndromic panel for bloodstream infections (FilmArray Blood Culture ID panel) have become available for rapid identification of $C$. albicans/Candida

Table 47.2 US FDA-cleared syndromic molecular tests

\begin{tabular}{|c|c|c|c|c|}
\hline Manufacturer & Test name & Syndrome & \# targets & Date cleared \\
\hline \multirow[t]{3}{*}{ Luminex } & xTAG respiratory viral panel (RVP) & Respiratory & 12 & $01 / 2008$ \\
\hline & NxTAG respiratory pathogen panel (RPP) & Respiratory & 20 & $12 / 2015$ \\
\hline & xTAG gastrointestinal pathogen panel (GPP) & GI tract & 14 & $01 / 2013$ \\
\hline \multirow[t]{5}{*}{ Nanosphere } & Verigene respiratory virus + test & Respiratory & 8 & $01 / 2011$ \\
\hline & Verigene gram-positive blood culture test & Bacteremia & 15 & $06 / 2012$ \\
\hline & Verigene enteric test & GI tract & 9 & $06 / 2014$ \\
\hline & Verigene gram-negative blood culture test & Bacteremia & 14 & $11 / 2014$ \\
\hline & Verigene respiratory pathogens flex NA test & Respiratory & 16 & $09 / 2015$ \\
\hline \multirow[t]{4}{*}{ bioMérieux/BioFire } & FilmArray respiratory panel & Respiratory & 20 & $05 / 2011$ \\
\hline & FilmArray blood culture identification panel & Bacteremia & 27 & $06 / 2013$ \\
\hline & FilmArray gastrointestinal panel & GI tract & 22 & $05 / 2014$ \\
\hline & FilmArray meningitis/encephalitis panel & CNS & 14 & $10 / 2015$ \\
\hline GenMark & eSensor respiratory viral panel & Respiratory & 14 & $02 / 2012$ \\
\hline Prodesse & ProGastro SSCS assay & GI tract & 5 & $01 / 2013$ \\
\hline
\end{tabular}


parapsilosis, C. glabrata/Candida krusei, and Candida tropicalis from positive blood cultures [91, 106-108].

Several real-time PCR assays have been developed over the last few years with varied level of sensitivity and specificity and often with limited range, only targeting a few Candida or mold species [109-113]. A recent shift toward development of pan-fungal assay can be observed in the literature and reflect the need for tools that detect most of the clinically relevant fungal pathogens in patient specimens [114-117].

More recently, a few commercial assays and reagents have become available for the detection of mold directly from specimens. Several MycArray ${ }^{\mathrm{TM}}$ assays (Myconostica Ltd., UK) targeting yeasts, Aspergillus species, and Pneumocystis jirovecii are commercially available outside of the United States and demonstrates high sensitivity and specificity compared to culture or LDT assays [118-120]. Other molecular methods used for fungal diagnosis include sequence-based identification using the ITS1 and ITS2 regions between the $18 \mathrm{~S}$ and $28 \mathrm{~S}$ rRNA subunits and the D1/D2 region of the 25-28S large ribosomal subunit [121]. Several studies have been published showing the utility of sequencing for fungal identification, and in some laboratories, sequencing has completely replaced the use of phenotypic methods to identify fungi growing in culture [122-126].

Unlike bacteria and fungi, molecular methods for detection of viruses are well established and for most pathogens are considered the gold standard. As such, there is extensive literature on the development and applications of molecular assays for the detection of viruses of importance to transplant patients including herpesviruses (Cytomegalovirus and Epstein-Barr viruses), polyomavirus (BK and JC virus), hepatitis viruses, and respiratory viruses [80, 127].

One of the first application of molecular assays in virology included qualitative and quantitative real-time PCR assays for the diagnosis and monitoring of human immunodeficiency virus (HIV), hepatitis B virus (HBV), and hepatitis $\mathrm{C}$ virus (HCV). These assays have been extensively evaluated and shown to be useful for the management and monitoring of patients with these infections [128-132]. A variety of commercial tests based on PCR (or RT-PCR) combined with sequencing (i.e., TRUGENE HIV-1 Genotyping Kit and ViroSeq genotyping system) or hybridization (i.e., INNO-LiPA HBV DR v2) are available for genotypic resistance testing of HIV [133, 134], HBV [135, 136], and HCV [137, 138].

Similarly, quantitative viral load testing has been developed for monitoring of viruses of importance to various transplant groups including cytomegalovirus (CMV), Epstein-Barr virus (EBV), BK virus, JC virus, and adenoviruses [80]. However, the biggest challenge associated with the use of these laboratory-developed quantitative assays is the inability to compare viral load results obtained across laboratories due to differences in genomic target (single vs multi-copy genes), extraction methods (manual vs automated), detection platforms, and lack of international standards and calibrators [139]. These limitations of quantitative assays have made the establishment of useful quantitative threshold for treatment difficult to establish [140-145]. The recent introduction of the first World Health Organization (WHO) international standards for cytomegalovirus [146] and Epstein-Barr viruses [147] as well as the availability of the first FDA-approved commercial real-time quantitative assay for monitoring of CMV viral loads was aimed at decreasing the variability in viral loads measured across methods, but a recent study by Hayden et al. showed that although improved, the standardization challenge remains in the field [148].

Other useful molecular assays for transplant patients include genotypic assays for drug resistance testing. Because transplant patients are often on prolonged antiviral therapy, these patients tend to develop mutations. These mutations can be detected by real-time PCR assays targeting known existing mutations that confer resistance to certain drugs, i.e., CMV UL97 mutations for ganciclovir or sequencing assay to detect all wild-type variants [149].

Several molecular assays have received FDA clearance for detection of respiratory viruses (Tables 47.1 and 47.2). The configuration of these assays varies from single target to highly multiplexed assays. The first FDA-cleared multiplexed molecular assay for respiratory viruses, the xTAG® Respiratory Viral Panel (RVP) (Luminex Molecular Diagnostics, Toronto, Canada), targets 12 viruses and subtypes (respiratory syncytial viruses $\mathrm{A}$ and $\mathrm{B}$; influenza A (H1 subtype, H3 subtype, and untypeable); influenza B; parainfluenza 1, 2, and 3; human metapneumovirus; adenovirus; and enterovirus/rhinovirus). This assay provided a significant improvement in the diagnosis of respiratory viral infections compared to conventional method and was instrumental in the rapid diagnosis of influenza A H1N1 during the 2009 outbreak in New York City [150, 151]. Additional multiplex molecular assays have since been approved including the FilmArray Respiratory Viral Panel (FA RVP) (BioFire Diagnostic Inc., Salt Lake City, Utah) FDA cleared for the detection of 17 viruses and subtypes including the virus targets in xTAG RVP plus human coronaviruses (NL63, HKU1, 229E, and OC43) and parainfluenza 4 as well as three bacterial targets: Bordetella pertussis, Chlamydia pneumoniae, and Mycoplasma pneumoniae. Multiple studies have been published comparing these highly multiplexed assays against each other, against monoplexed assays, and against traditional methods in various patient populations [152-157]. Results have shown comparable performance with overall sensitivity and specificity between $90 \%$ and $100 \%$, although differences were detected for specific targets including adenoviruses, which are detected with higher sensitivity by 
single target assays than by highly multiplexed PCR [156]. Other molecular devices for detection and identification of a panel of respiratory viral pathogens are also commercially available from several manufacturers including Gen-Probes (Prodesse assays), Focus Diagnostics (Simplexa assays), and Nanosphere, Inc. (Verigene assays) [158, 159].

A parasite of interest for transplant patients, especially those undergoing heart transplantation, is Toxoplasma gondii, which can be due to either reactivation of latent infection or acquisition of parasites from transplanted organs [160]. Unlike immunocompetent hosts, the diagnosis of toxoplasmosis in immunocompromised patients, including transplant recipients, is most effectively done using PCR on the appropriate specimens $[160,161]$.

\section{Transcriptomic Assays}

Genomic assays detect microbial organism-specific nucleic acids; therefore, a positive result can occur with both alive and dead microorganisms, which is particularly true for those pathogens that have protective cell wall. The best example of this is the detection of Mycobacterium tuberculosis DNA in sputum where the dead microbial pathogen DNA can remain un-degraded due to the fatty acid-rich cell walls [162, 163]. Unlike the results of a function-based testing method, such as mycobacterial cultures, in the clinical setting, a positive PCR result after antituberculosis therapy does not necessarily mean treatment failure. Therefore, DNA-targeted molecular assays are usually not considered to be tests of cure. This is also true for sexually transmitted pathogens such as Chlamydia trachomatis and Neisseria gonorrhoeae [164]. A positive result may reflect treatment failure with persistent infection but may also reflect resolved infection by detecting the mere presence of ribosomal RNA debris and nonviable C. trachomatis DNA [165].

To overcome this disadvantage, transcriptomic assays have been explored. The ability of mRNA-based assays to distinguish viable from nonviable organisms suggests that such assays should be useful in monitoring the efficacy of antituberculosis therapy [166-170]. For monitoring efficacy of therapy, mRNA RT-PCR results paralleled well with those of culture at the follow-up time points [163]. Another study further demonstrated sputum $M$. tuberculosis mRNA is a reliable marker of bacteriologic clearance in response to several mono or combined antituberculosis therapies [162]. Nucleic acid amplification assays targeting microbial mRNA have also been used for diagnosis and assessment of human papillomavirus (HPV) infections. Several reports have shown not only the ubiquitous presence of E6 and E7 mRNA in cervical cancer but also a quantitative difference in the overexpression of E6/E7 depending on the severity of the cervical lesion [171]. Several E6 and E7 mRNA qualitative assays including Aptima (Gen-Probe), NucliSENS EasyQ HPV (bioMérieux), and PreTect HPV-Proofer (NorChip) have been reported to improve the low specificity and positive predictive value of HPV DNA assays [172].

Advances in molecular biology technologies, especially the real-time quantitative PCR formats, have made the implementation of mRNA-based assay relevant and accurate. Another novel approach known as RNA-seq, which uses next-generation sequencing technologies to generate transcriptome profiling [173], is starting to come into the diagnostic microbiology field [174, 175]. Using dual-species transcriptional profiling in a murine model of systemic candidiasis, Hebecker et al. observed a delayed transcriptional immune response accompanied by late induction of fungal stress response genes in the kidneys. In contrast, early upregulation of the proinflammatory response in the liver was associated with a fungal transcriptome resembling response to phagocytosis, suggesting that phagocytes contribute significantly to fungal control in the liver [176]. Rasmussen et al. combined longitudinal, dimensionality reduction and categorical analysis of the transcriptome from 111 liver biopsy specimens taken from $57 \mathrm{HCV}$-infected patients over time and identified alterations in gene expression that occur before histologic evidence of liver disease progression, suggesting that events that occur during the acute phase of infection influence patient outcome [177].

In contrast to these "fancy" and advanced technologies, transcriptomic assays face basic specimen source-related challenges. Currently, there are limited methods which can be used to differentiate and overcome the DNA contamination when mRNA targets are tested. Theoretically, specimens can be pre-treated with DNAase prior to the mRNA amplification and detection [178, 179]. However, absolutely RNase-free DNAase is rarely available to actually do the job. Designing primers/probes to cover RNA splicing sites has been demonstrated efficient if relevant RNA splicing sites are available in targeted bacteria and viruses [180, 181]. Indirect methods have been reported to determine antimicrobial susceptibility by selectively detecting viable microorganisms. This assay uses a DNA-binding dye that penetrates damaged bacterial cells and renders DNA un-amplifiable, thereby decreasing background amplification from killed organisms [182, 183].

\section{Proteomic Assays}

One leading proteomic technology, matrix-assisted laser desorption ionization-time of flight mass spectrometry (MALDI-TOF MS), has emerged as a rapid and powerful tool for microbial species identification [100]. The analyte molecules embedded within the saturated matrix on the target plate are irradiated by a laser of special wavelength and intensity, inducing desorption and ionization; the charged 
analytes then are accelerated by an electric field in a flight tube to a detector, where they are captured. The separation of various molecules depends on the time of flight, which is reversely proportional to the mass of molecules. After detection signals are processed and interpreted into the mass spectra, the characteristic mass peaks are used to characterize and eventually identify the microorganisms. By measuring the exact sizes of peptides and small proteins, which are assumed to be characteristic for each bacterial species, it is possible to determine the species within a few minutes of when the analysis is started with whole cells, cell lysates, or crude bacterial extracts [184-186].

Numerous reports have shown that MALDI-TOF MS has revolutionized the routine identification of microorganisms in clinical microbiology laboratories by introducing an easy, rapid, high-throughput, low-cost, and efficient identification technique [187-190]. Two such systems, the Bruker Biotyper (Bruker Daltonics Inc., Billerica, MA) and Vitek MS (bioMérieux Inc., Durham, NC), have been successfully used in the routine clinical microbiology laboratory [191, 192]. A recent comparative study was performed on five methods for differentiation of coagulase-negative staphylococci (CoNS), i.e., Vitek2 (Gram-positive card REF 21342; bioMérieux), the ID 32 Staph strip (bioMérieux), partial 16S rRNA gene sequencing (MicroSeq; Applied Biosystems), partial tuf gene sequencing (in-house), and MALDI-TOF MS (Bruker Daltonics), on 142 CoNS clinical isolates. MALDI-TOF MS showed the best results for rapid and accurate CoNS differentiation with $99.3 \%$ of strains correctly identified [193]. In addition to microbial identification from purified colonies, the MALDI-TOF MS has been successfully used directly from urine and positive liquid culture media [194-197].

In addition to rapid identification of microorganisms, MALDI-TOF MS has been explored for determining epidemic relatedness and antibiotic resistance of microbial isolates. The utility of MALDI-TOF MS for microbial typing was investigated in Staphylococcus aureus in two recent studies. The composition correlation index analysis of the MALDI-TOF MS data demonstrated the similar inter-strain relatedness found with the standard typing methods used to confirm the outbreak [198, 199]. These data indicated that this technology is a potential rapid screening tool for nosocomial infection investigations. The MALDI-TOF MS was capable of rapidly and accurately identifying mecA-positive $S$. aureus and vanB-positive Enterococcus faecium from susceptible isolates [200, 201]. The MALDI-TOF MS has been directly used to determine mechanisms of antibiotic resistance [202]. Bittar et al. described the use of a MALDITOF MS profile and a ClinPro Tools software to detect and identify staphylococcal Panton-Valentine leukocidin [203]. The detection and identification of a series of $\beta$-lactamases from Gram-negative bacilli by MALDI-TOF MS seem to be a powerful, quick, and cost-effective method for clinical microbiology laboratories [204-207]. These studies represented a proof of concept for the use of MALDI-TOF MS technology as a rapid method to timely monitoring microbial infections.

Numerous proteomic biomarkers have been used to diagnosis and monitoring of microbial infections. One of the most promising biomarkers in recent years is procalcitonin (PCT). PCT has many favorable properties as it is rapidly induced during infections and has a long half-life with capacity to differentiate bacterial from viral etiologies [208]. For the use and value of procalcitonin in SOT transplantation, the existing literature suggests reasonable sensitivity and specificity for the PCT test in identifying infection complications among patients undergoing transplantation. Monitoring PCT in the early posttransplant period seems to be a promising method for early detection of infectious complications; however, given the imperfect sensitivity and specificity of the PCT test, medical decisions should be based on both PCT test results and clinical findings [209, 210]. Recently, van Houten et al. reported the use of a three-host protein (TRAIL, IP-10, and CRP)-based assay to differentiate between bacterial and viral infections in children with lower respiratory tract infection or fever without source [211].

\section{Metabolic Assays}

Diagnosing bacterial infections by smell has been practiced for millennia. Volatile organic compounds (VOCs), produced by bacteria as metabolites, may be produced in different quantities and combinations by each bacterial species or serovar, generating characteristic odors. These compounds, in combination with other VOCs, could be used as a volatile fingerprint of each bacterium. Recently, fast and sensitive techniques, led by a variety of mass spectrometry platforms, have been developed and implemented to detect and characterize microbial pathogens based on microbial metabolite analysis [212]. In addition, metabolic analysis can be used for functional characterization including virulence and resistance determination. Gilreel et al. recently examined the metabolic potential of multidrug-resistant uropathogenic Escherichia coli and demonstrate metabolic activity of members of the ST131 lineage correlated with antibiotic susceptibility profiles [213].

Direct detection of exogenous fungal metabolites in breath may be used as a novel, noninvasive, species-specific approach to identify patients with invasive aspergillosis (IA), potentially allowing more precise targeting of antifungal therapy and fewer invasive diagnostic procedures. Gas chromatography coupled with mass spectrometry (GC-MS) has been the mainstay for the detection and characterization of VOCs produced by a panel of Gram-negative bacilli [214216]. Unique GC-MS VOCs were found to be produced by 
five Aspergillus species such as A. fumigatus, A. versicolor, A. sydowii, A. flavus, and A. niger cultivated on malt extract agar and gypsum board [217]. In another study, 2-Pentylfuran (2PF) was consistently detected in the media of $A$. fumigatus, Fusarium spp., A. terreus, and A. flavus and to a lesser extent by $A$. niger. $2 \mathrm{PF}$ was detected in breath samples from 4/4 patients with cystic fibrosis and A. fumigatus colonization, $3 / 7$ patients with cystic fibrosis but no microbiological evidence of $A$. fumigatus, and none of the 10 healthy controls [218]. Using thermal desorption-GC-MS, Koo et al. characterized the in vitro volatile metabolite profile of A. fumigatus. A pathogen-specific metabolic signature combined with $\beta$-trans-bergamotene, $\alpha$-trans-bergamotene, a $\beta$-vatirenenelike sesquiterpene, and trans-geranylacetone accurately discriminated patients with IA from patients with other pneumonia [219]. Besides Aspergillus species, VOCs such as nicotinic acid have been found to be promising biomarkers for Mycobacterium tuberculosis infections [220].

\section{Clinical Perspective}

During the last 10 years, mortality related to infection after HSCT has declined substantially [221]. Nonetheless infection remains a substantial cause of non-relapse mortality. Use of alternative donors such as cord blood and haploidentical donors, older age at transplant, and increased comorbidities continue to increase [222, 223]. These transplant characteristics have been associated with increased infection risk. Furthermore neutropenia, T-cell depletion, GVHD, and immunosuppressive agents continue to shape the spectrum and period of risk for specific infections. Our expanding knowledge of the role of the human microbiome in the outcomes of transplantation provides new challenges and opportunities for clinical interventions.

Management of infections in the immunocompromised host poses several challenges. Inflammatory host responses are usually reduced or absent. Patients with life-threatening infections may present with minimal signs and symptoms and deteriorate rapidly often developing disseminated disease. Organisms of little or no pathogenicity for healthy individuals may cause life-threatening infections, and multiple pathogens may coexist in the same patient. Invasive procedures needed to maximize diagnostic accuracy may be not feasible due to thrombocytopenia or other conditions. Timely institution of broad empiric therapy is essential to improved outcomes; yet polypharmacy may lead to substantial toxicities and serious drug interactions.

The increasing implementation of nucleic acid-based assays in clinical practice has enabled rapid and often quantifiable diagnosis of an expanding list of organisms. Clinical decision-making is complex as quantification enables realtime monitoring of pathogen replication dynamics.
Table 47.3 Clinical applications of diagnostic assays in immunocompromised patients

\begin{tabular}{l|l} 
Level & Goal \\
\hline $\begin{array}{l}\text { Prevention } \\
\text { Preemptive }\end{array}$ & $\begin{array}{l}\text { Risk assessment } \\
\text { Testing asymptomatic patients at risk for disease }\end{array}$ \\
\hline Diagnostic & $\begin{array}{l}\text { Testing patients with clinical signs and symptoms of } \\
\text { infection for specific pathogens }\end{array}$ \\
\hline Therapeutic & $\begin{array}{l}\text { Testing patients with established infection to direct } \\
\text { treatment, assess response to therapy, and evaluate } \\
\text { prognosis }\end{array}$ \\
\hline Prognostic & Test patients at risk for recurrence of disease
\end{tabular}

Diagnostic assays are used by the clinicians to predict risk of infection in asymptomatic patients, monitor patients at risk for disease, diagnose disease in symptomatic patients, or monitor response to therapy or predict outcomes in patients with established disease (Table 47.3).

\section{Prediction of Risk for Infection}

The pretransplant evaluation of donors and recipients of HSCT includes serology to determine prior exposure to pathogens. The Federation for Accreditation of Cellular Therapies (FACT) requires donors and recipients to be tested for antibodies to HIV, human T-cell lymphotropic viruses I and II, HBV, $\mathrm{HCV}$, and herpes viruses (HSV, VZV, CMV, EBV). Donors and recipients are tested for exposure to West Nile virus and Trypanosoma cruzi. Donors should be tested within 30 days prior to collection. Emergence of pathogens with potential for transmission through cellular products requires development of new diagnostic assays. A recent example is Zika virus. A non- FDA approved test is currently used to screen blood donors (https://www.cdc.gov/zika/transmission/bloodtransfusion.html). However the current CDC recommendations to reduce transmission of Zika through human cells and cellular-based products are based on epidemiologic history (https://www.fda.gov/downloads/BiologicsBloodVaccines/ GuidanceComplianceRegulatoryInformation/Guidances/ Tissue/UCM488582.pdf).

Based on the results of the pretransplant tests, clinicians assess risks, benefits, and alternatives to HSCT or implement preventive treatment. For example, recipients with positive IgG antibody for hepatitis B (HBV) core antigen (with negative HBV surface Ag and negative HBV PCR) are treated with entecavir to prevent reactivation of $\mathrm{HBV}$ posttransplant.

CMV serology of the donor and recipient has major implications. For recipients with acute CMV infection indicated by positive CMV IgM (negative $\operatorname{IgG}$ ), transplant may be delayed, and treatment may be required. The CMV serostatus of the recipient is the most important predictor for development of CMV infection posttransplant. Combined results of donor and recipient serology is used to optimize donor selection [224] . Given the availability 
several donors with similar degree of HLA match, preference is given to donor matching the CMV serostatus of the recipient. For CMV-seronegative patients, the use of a $\mathrm{CMV}$-seronegative donor alleviates the risk of CMV transmission through the allograft [225]. CMV-seropositive recipients who receive conventional allografts from $\mathrm{CMV}$ seropositive donors are receiving CMV-specific cytotoxic $\mathrm{T}$ lymphocytes (CTL) contained in the allograft. Lymphocytes from CMV-seropositive donors can also be used to generate ex vivo CMV CTL for adoptive immunotherapy posttransplant [226]. The CMV serostatus of donor and recipient also determines the need for posttransplant serial monitoring for CMV. Recipients who are CMV positive or receive grafts of CMV-seropositive donors are monitored by CMV PCR, and preemptive therapy is initiated, if CMV infection occurs [227]. Another approach is antiviral prophylaxis for CMV for high-risk groups such as recipients of mismatched or T-cell-depleted allografts [228]. It will be interesting to assess whether CMV monitoring by the PCR will eliminate survival differences between $\mathrm{CMV}$-seropositive and $\mathrm{CMV}$ seronegative recipients.

Additional screening may be indicated for donors and recipients of T-cell-depleted grafts. Toxoplasma serology is not required by FACT and is tested per institutional practices. Patients receiving T-cell-depleted allografts are at higher risk of toxoplasmosis compared to patients who receive conventional allografts. Thus recipients of T-cell-depleted allografts may be candidates for prophylaxis against toxoplasma posttransplant. At present the interpretation of serology is qualitative (positive vs negative). Recent studies suggest that the magnitude of titers may be relevant in predicting disease risk. Meers et al. reported that high titers of toxoplasma IgG pretransplant were associated with increased risk of toxoplasmosis after HSCT [229]. Given the low frequency of toxoplasmosis in HSCT, a multicenter study would be required to confirm these findings.

The notion that the magnitude of IgG titers may be useful as a predictor for infection posttransplant was also supported by a pilot study assessing pretransplant antibodies to adenovirus (ADV). In that study, patients with high pretransplant IgG titers to a specific ADV serotype were more likely to develop ADV infection with the same ADV serotype after HSCT [230].

Patient exposures may also indicate the need for additional testing. For example, QuantiFERON Gold TM testing for detection of latent tuberculous infection is pertinent for transplant candidates from endemic areas for $M$. tuberculosis [231, 232]. Patients with latent tuberculous infection pretransplant will require treatment posttransplant. Pretransplant stool examination for ova and parasites for transplant candidates coming for endemic areas of Strongyloides stercoralis or empiric treatment for Strongyloides stercoralis pretransplant could be employed for such individuals [233].

\section{PCR Assays for Detection of Double-Stranded (ds) DNA Viruses}

The availability of commercially available quantitative PCR assays for many dsDNA viruses has enabled the detection of these viruses in body compartments such as blood, urine, stool, bronchoalveolar lavage (BAL), or cerebrospinal fluid. While PCR assays provide accurate and rapid identification and quantification, several challenges remain regarding their optimal use and interpretation of results.

\section{Cytomegalovirus (CMV)}

CMV is an important cause of morbidity and mortality in transplantation. The biologic properties and natural history of CMV are well defined [234]. CMV viremia occurs frequently after HSCT and in most instances precedes development of end-organ CMV disease. Effective antiviral treatment is available, and preemptive treatment of CMV infection has been shown to be effective in preventing endorgan disease [235]. Routine monitoring is recommended for patients at risk for CMV disease [236, 237]. Currently PCR-based assays for CMV have replaced pp65 antigenemia assay in most centers. Green et al. reported that transition of preemptive therapy strategy from antigenemia to PCR-based monitoring and host risk factors successfully prevented CMV disease without increasing the proportion of patients receiving preemptive therapy and attributable toxicity [238]. The performance characteristics of individual CMV PCR assays vary; thus cutoff values and thresholds for treatment are not comparable among laboratories [145]. The availability of the World Health Organization (WHO) International Standard (IS) for CMV for nucleic acid amplification techniques is an important development for decreases variance between laboratories and enables to develop international clinical practice guideline [227]. Even with the WHO standardized assay, there is considerable variability (up to $1.5 \log _{10} \mathrm{IU} /$ $\mathrm{mL}$ ) in different determinations of viral load from the same specimen [239].

\section{Other Double-Stranded (ds) DNA Viruses}

BK polyomavirus (BKV), adenovirus (ADV), and human herpesvirus 6 (HHV-6) are detected with variable frequencies in HSCT patients, yet their natural history is not fully understood. All these viruses have been associated with potentially serious end-organ disease and adverse transplantation outcomes. Yet the utility of routine monitoring and preemptive intervention have not been evaluated in prospective clinical trials. Because of the relatively low frequency of end-organ disease caused by these viruses, multicenter studies would be better suited to address such questions. Differences in diagnostic assays and clinical practices among institution and lack of approved treatments for these pathogens pose logistical difficulties. 


\section{BK Polyomavirus (BKV)}

BK polyomavirus (BKV) is identified as a cause of allograft nephropathy in kidney transplants (BKVAN) and a cause of hemorrhagic cystitis in HSCT recipients [233, 240]. In renal transplant recipients, several studies have directly linked BKV replication to BKV nephropathy (BKVN), and BKV viremia is a predictor of BKVN in renal allografts [241]. Furthermore an association between the magnitude of BKV viral load in the blood and development of BKVN has been well described, and appropriate cutoffs have been established for the clinical significance of BKV viremia. BKVN cases have been reported in HSCT recipients [242-244]. The diagnosis for BKVN in HSCT recipients is challenging as kidney biopsy is oftentimes not feasible due to thrombocytopenia and bleeding risk.

The exact biologic relationship between BKV and hemorrhagic cystitis in HCT recipients is not well understood [245-252]. Some studies have shown a relationship between the magnitude of urine BKV viral load and development of hemorrhagic cystitis [253-255]. However the concentrations of virus vary widely and often overlap with patients who do not develop hemorrhagic cystitis. Unfortunately, no effective therapy is currently available for the prevention or treatment of symptoms associated with BKV, in large part due to a lack of understanding about its etiology and pathogenesis [256-261]. It is likely that the pathophysiology of cystitis in this setting is multifactorial with $\mathrm{BKV}$ reactivation as a contributing factor. The level of BKV viruria in HSCT exceeds by several logs the levels observed in renal transplants [250, 251, 254, 262]. Reduction of immunosuppression, the mainstay for management in renal transplantation, is not an option in the allogeneic HSCT due to the risk of triggering or exacerbating graft-versus-host disease. Despite the lack of established guidelines for the interpretation of BKV PCR results in HSCT and paucity of therapeutic measures for BKV in HSCT, BKV PCR is frequently ordered in symptomatic patients.

At our institution we prospectively monitored in 100 adult HSCT recipients for BKV in the urine by Q-PCR every 2 weeks from beginning of conditioning until week +15 posttransplant [252]. We found that $50 \%$ of patients had $\mathrm{BKV}$ viruria by day +30 , and the rate remained stable for the duration of the study. Ten (10\%) patients developed hemorrhagic cystitis (grade $\geq 2$ by Bedi et al. [245]. Seven (70\%) patients with hemorrhagic cystitis had BKV in the urine (two with concomitant adenovirus). In univariate analyses, high BKV viral load $\left(\geq 1.0 \times 10^{7}\right.$ copies $\left./ \mathrm{mL}\right)$ and older age were predictors of hemorrhagic cystitis. During the study period, 36 patients died and 8 patients had autopsies performed. One patient was found to have BKVN at autopsy. Our findings suggest that factors in addition to BKV are likely involved in the pathogenesis of hemorrhagic cystitis posttransplant. At present, we do not recommend monitoring asymptom- atic patients for BKV in urine. In patients with symptoms of cystitis and no other identified etiology, we suggest checking $\mathrm{BKV}$ PCR once. We discourage monitoring of BKV viral load in the urine in patients with known BKV viruria. BKV nephropathy should be considered as a cause of renal dysfunction in severely immunosuppressed HSCT patients without any other obvious etiology.

\section{Adenovirus (ADV)}

Adenovirus infection occurs in $<5-20 \%$ of HCT recipients depending on patient age, type of transplant, and degree of immunosuppression [263-265]. ADV-associated hepatitis, pneumonitis, and encephalitis are frequently fatal, while colitis and hemorrhagic cystitis cause substantial morbidity and may contribute to mortality [266-268]. More than 50 ADV serotypes are identified and differ in terms of frequency, tropism, and potential for disease severity [269]. ADV viremia has been associated with decreased overall survival after HSCT [270, 271].

Quantitative PCR assays for ADV have replaced for most part culture or antigen assays. Routine surveillance for ADV is suggested for high-risk patients such as recipients of T-cell-depleted transplant (TCD), cord blood transplant, or haploidentical transplant or for patients with refractory GVHD [272-274]. The American Society of Bone Marrow Transplant recommends serial monitoring for ADV by PCR during the first 6 months after HSCT or for the duration of severe immunosuppression and/or lymphopenia for patients at highest risk [275]. These recommendations are based on single-center experience and expert opinion but not validated in controlled trials. Ohrmalm et al. found little utility in serial monitoring of plasma ADV PCR in a cohort of 97 HSCT comprised of 64\% T-cell-depleted allografts [276]. High level or rising ADV viremia has been reported to predict disseminated ADV disease and death [277-280]. Rising ADV viral load in the stool has also been reported as a useful predictor of ADV disease [279]. T-cell depletion, younger age, and GVHD have been associated with invasive ADV disease [266, 277-279]. Cidofovir has been used in established ADV disease and ADV viremia, yet its efficacy is based on small noncontrolled studies and case series [272274]. Brincidofovir, a novel, orally administered, broadspectrum antiviral active against ADV, has shown promising results in case reports [277, 281, 282]. A small randomized placebo-controlled clinical trial of preemptive treatment of ADV viremia with brincidofovir confirmed the antiviral activity in HCT patients however [283]. A subsequent openlabel phase III study evaluated brincidofovir treatment for localized or disseminated ADV infection in adult and pediatric HSCT recipients. Virologic response was correlated with lower ADV viral load at start of treatment and earlier start of brincidofovir after ADV diagnosis. Gastrointestinal-related (abdominal pain, diarrhea, nausea, vomiting) symptoms 
were most common adverse events and led to treatment discontinuation especially in adult HCT.

Since 2012, we have implemented routine blood PCR monitoring from day+14 until day+100 posttransplant in TCD and cord blood HSCT recipients. The rate of ADV viremia was $8 \%$, and $33 \%$ of viremic patients developed ADV disease in TCD HSCT recipients. ADV disease was diagnosed within 60 days posttransplant, and $85 \%$ of patients with ADV diseases died. The benefit of preemptive therapy for $\mathrm{ADV}$ for prevention of ADV disease in recipients of TCD grafts should be evaluated in prospective clinical trials.

\section{Human Herpesvirus 6 (HHV-6)}

HHV-6 infects over $90 \%$ of individuals in the first 18 months of life. After resolution of the primary infection, the virus establishes latency mainly in CD34+ cells including monocytes and macrophages. An alternative form of HHV-6 persistence is integration of viral sequences into host cell chromosomes [284]. Approximately 40\% of all HSCT recipients develop HHV-6 reactivation, and the cords rates may be $>90 \%$ [285]. At our Institution 61\% CD34+ selected HCT and $94 \%$ cord blood recipients (without ATG) developed early HHV6 viremia. Rates of HHV6 encephalitis were low in our patients, $0.7 \%$ and $1.6 \%$ in $\mathrm{Cd} 34+$ and cord blood, respectively [286].

HHV6 has been associated with a host of indirect consequences such as acute GVHD, CMV reactivation, and mortality after HSCT [287]. Zerr et al. suggest HHV-6 reactivation is associated with delirium and neurocognitive decline after HSCT [288]. The most recognized and severe form of HHV-6 is posttransplant acute limbic encephalitis (PALE). Hill et al. examined a cohort of 1243 adult donor HSCT and 101 umbilical cord transplants to identify risk factors for PALE. In multivariate analyses cord blood transplant, grade II-IV GVHD and adult mismatched donor were significant. While viral loads for HHV-6 were higher in patients with PALE, values greatly overlapped. Furthermore, peak values were detected a median 1 day to 9 days form symptom onset [289]. Foscarnet, cidofovir, and ganciclovir are available antiviral agents that demonstrated in vitro activity against HHV-6, but there are no controlled trials to study these agents for HHV-6 therapy. A few studies evaluating the efficacy of preemptive or prophylactic therapy to prevent PALE have been disappointing [290-292].

\section{Diagnostic Evaluation of Specific Syndromes}

\section{Challenges}

Infectious complications in transplant patients are often extremely complex to assess since there is a wide array of pathogens that can cause infections, including bacteria, viruses, fungi, and parasites. Further, patterns of pathogen infectivity vary tremendously, particularly in the setting of HSCT in which immune recovery plays a major role in defining the type and clinical presentation of many infections. Infections may occur as acute events such as a pneumonia or bloodstream infection, reactivation of latent organisms as in the case of herpesvirus infections, and colonization without true invasive infection or as recurrent, nonresponding, or resistant infections. Furthermore, sites of infections may be localized to a single body area or tissue or may be disseminated. HSCT recipients may be suffering from immune incompetence that can last for years.

Multiplex assays offer the advantages when the quantity of sample is limited as they provide information on multiple pathogens. Combination of multiple diagnostic platforms in the same sample and testing of several body compartments cast a wider net and expand diagnostic capabilities. We present specific challenges in clinical evaluation of pulmonary syndromes in HSCT patients.

\section{Evaluation of Pulmonary Syndromes}

\section{Viral Infections}

The use of PCR to analyze samples from HSCT recipients may facilitate early detection of respiratory viruses, even prior to onset of symptoms when viral loads are likely to be low. For symptomatic patients, PCR testing provides a sensitive diagnostic approach to identify the etiology of respiratory symptoms and an appropriate isolation of the ill patient. Additionally, quantitative RT-PCR assays can be used to initiate appropriate treatment and monitor changes in viral load during therapy.

Some respiratory viruses such as RSV, parainfluenza viruses, adenovirus, and influenza viruses are known to cause low respiratory infections associated with substantial morbidity and mortality in immunosuppressed patients. In contrast the correlation of the presence of rhinovirus or coronavirus in the upper respiratory tract with development of lower respiratory infection in HSCT is not clear [293]. The correlation between magnitude of viral load in bronchoalveolar lavage fluid and pneumonia or transplant outcomes is currently being investigated for a variety of viruses [294, 295].

The use of nucleic acid assays may contribute to identification of organisms not previously associated with pulmonary disease. Enterovirus D68 was recently associated with acute respiratory distress syndrome in infants and HSCT [293, 296]. Human metapneumovirus (hMPV) and human bocavirus have been reported as a cause of severe lower respiratory tract infection [297-299]. Two new human polyomaviruses, KI polyomavirus (KiPyV) and WU polyomavirus (WUPyV), are found in one third of allogeneic HSCT recipient's respiratory specimens during the first year posttransplant, but the associations with respiratory symptoms are unclear [300]. 


\section{Invasive Fungal Infections}

Diagnosing invasive pulmonary aspergillosis (IPA) remains a challenge. Tissue diagnosis is ideal, yet invasive procedures may not be feasible in critically ill patients especially those with cytopenia. Isolation of Aspergillus species from BAL may represent colonization or invasive infection depending on species and clinical context. For example, Aspergillus versicolor and Aspergillus niger are often not associated with disease when they were isolated from BAL specimens [301, 302]. Cytology in combination with traditional culture techniques may improve diagnostic yield. In a retrospective study comparing diagnostic yield of cytology and culture for septate, mold infections (cytology of BAL and bronchial wash specimens) had higher yield compared to culture of tissue (autopsy and biopsy) samples (58\% vs 30\%, $P<0.03)$ [303].

Noninvasive sensitive tests are needed for the diagnosis of mold infections. Detection of an Aspergillus secondary metabolite signature in a simple breath test showed $94 \%$ sensitivity and $93 \%$ specificity in diagnosis of IPA in a small preliminary study [219]. Such tests offer promising alternatives for patients that cannot undergo bronchoscopy.

Molecular-based assays are expected to allow a rapid diagnosis of Aspergillus and non-Aspergillus invasive fungal infections with a high sensitivity. In a recent multicenter prospective study evaluation, addition of PCR to GM in BAL sampling improved the diagnosis of invasive aspergillosis [51]. Initial validation studies of the serum GM assay reported $61 \%$ sensitivity and $93 \%$ specificity in probable and proven IPA; however, the sensitivity of serum GM is considerably lower in setting of mold-active azole prophylaxis [304, 305]. Determination of GM in the BAL fluid may improve the diagnostic utility of this assay. In a prospective cohort study including 530 patients with hematologic malignancy, the sensitivity and specificity of BAL GM was $50 \%$ and $73 \%$ for detecting probable and proven IPA [306]. Further prospective studies are needed for the combination of these two diagnostic modalities for the diagnosis of proven and probable aspergillosis.

Fungal PCR has been useful in confirming diagnosis of invasive fungal infections when traditional cultures are negative especially in patients previously treated with antifungal agents. At our institution among 46 patients participating in a randomized trial for antifungal prophylaxis of fungal infection in neutropenic patients undergoing induction or re-induction chemotherapy, six patients underwent bronchoscopy for evaluation of pulmonary infiltrates. BAL was tested by cytology, traditional fungal cultures, GM, and universal fungal PCR. None of the patients had positive fungal cultures or positive GM in the BAL. Fungal PCR identified Rhodotorula nogopathi and Cryptococcus saitoi in one patient each. While these fungi are not recognized previously as pathogens in humans, our patients responded clinically when antifungal therapy was adjusted to target these organisms.
Traditional culture techniques are routinely used for diagnosis of candidemia. The clinical relevance of non-Candida species isolated from blood has to be interpreted with caution. In a retrospective study of non-Candida fungemia episodes in allogenic HSCT recipients, $42 \%$ of patients did not have clinically significant fungemia [307].

\section{Therapeutic Monitoring}

\section{Viral PCR}

Monitoring of the viral load to assess response to treatment is a well-established practice for CMV. CMV viral replication in the blood usually correlates with disease activity. Depending on CMV viral load, clinicians may continue treatment, change dose or type of antiviral, or discontinue treatment. Less evidence exist on the correlation of ADV or HHV-6 viral loads with disease activity, yet clinicians routinely use viral loads as an aid to treatment decisions.

Monitoring of viral load of respiratory viruses as a prognostic indicator of lower respiratory tract infection in HSCT patients is not a routine clinical practice at present. Recent studies suggest that this approach may be of value [294, 308].

\section{Genotypic Assays for Mutations Conferring Resistance to Antivirals}

Genotypic assays for antiviral resistance may offer clinical guidance in a timely fashion. Commercially available assays are available for cytomegalovirus. Resistance usually emerges after prolonged or subtherapeutic exposure to antivirals in the setting of immunosuppression [309]. CMV resistance to current antiviral agents is mediated by alterations in either the UL97 kinase or DNA polymerase, encoded by the UL97 and UL54 genes, respectively. UL97 mutations are capable of conferring resistance to ganciclovir, while UL54 mutations can impart resistance to ganciclovir, cidofovir, and foscarnet [310].

Studies correlating CMV genotypes and drug susceptibility phenotypes may further guide treatment decisions. This will improve the interpretation of sequence-based assays currently used for clinical diagnosis and guide the development of new antiviral drugs [311].

Resistance of influenza virus to antiviral agents is a concern in immunocompromised HSCT patients due to high grade and prolonged viral replication and prolonged exposure to antivirals. Rapid identification of emerging resistance during treatment would be helpful in modifying treatment [312, 313].

\section{Serial Monitoring of Fungal Burden Markers}

In patients with invasive aspergillosis and positive serum GM at baseline, serial monitoring of serum GM provides useful information on response to treatment and prognosis. Koo et al. 
reported that the combination of GM at baseline and at 1 week was predictive of all-cause mortality independent of other traditional risk factors for mortality and antifungal exposure [314]. In a prospective study, Bergeron et al. showed that (i) a poor day 45 outcome was strongly associated with a high baseline serum GM index; (ii) a consistently negative serum GM index during the follow-up was associated with a good outcome, in contrast to either a steady or an emerging positive GM index; and (iii) the day 14 clinical evaluation was predictive of the day 45 outcome [315]. In patients with treated Aspergillosis, rising GM levels after initial normalization raise concern for breakthrough infection and inadequate exposure of development of resistance to ongoing antifungal therapy.

\section{Summary}

In the last decade, nucleic acid-based assays have enhanced diagnostic sensitivity and specificity, shortened test turnaround time, provided automatic and high-throughput processing, and enabled quantification of microbial pathogens. A positive molecular test result indicates that targeted pathogen-specific nucleic acids are detected. For opportunistic pathogens in particular, clinical interpretation is crucial in determining the clinical significance of a positive test. Evolving genomics, transcriptomic, proteomic, and metabolomic technologies are being translated into clinical applications at a fast pace. Collaboration between laboratory and clinical medicine is paramount to ensuring optimal utilization and interpretation of diagnostic modalities.

\section{References}

1. Sayer HG, Longton G, Bowden R, Pepe M, Storb R. Increased risk of infection in marrow transplant patients receiving methylprednisolone for graft-versus-host disease prevention. Blood. 1994;84(4):1328-32.

2. Patel R, Paya CV. Infections in solid-organ transplant recipients. Clin Microbiol Rev. 1997;10(1):86-124.

3. Guerrant RL, Van Gilder T, Steiner TS, Thielman NM, Slutsker L, Tauxe RV, et al. Practice guidelines for the management of infectious diarrhea. Clin Infect Dis. 2001;32(3):331-51.

4. Hohenthal U, Itala M, Salonen J, Sipila J, Rantakokko-Jalava K, Meurman O, et al. Bronchoalveolar lavage in immunocompromised patients with haematological malignancy--value of new microbiological methods. Eur J Haematol. 2005;74(3):203-11.

5. Krones E, Hogenauer C. Diarrhea in the immunocompromised patient. Gastroenterol Clin N Am. 2012;41(3):677-701.

6. Kamboj M, Mihu CN, Sepkowitz K, Kernan NA, Papanicolaou GA. Work-up for infectious diarrhea after allogeneic hematopoietic stem cell transplantation: single specimen testing results in cost savings without compromising diagnostic yield. Transplant Infect Dis. 2007:9(4):265-9.

7. Zaidi AK, Macone A, Goldmann AD. Impact of simple screening criteria on utilization of low-yield bacterial stool cultures in a Children's hospital. Pediatrics. 1999;103(6 Pt 1):1189-92.
8. Ginsburg PM, Thuluvath PJ. Diarrhea in liver transplant recipients: etiology and management. Liver Transplant. 2005;11(8):881-90.

9. Glass RI, Parashar UD, Estes MK. Norovirus gastroenteritis. N Engl J Med. 2009;361(18):1776-85.

10. Logan C, O'Leary JJ, O'Sullivan N. Real-time reverse transcription PCR detection of norovirus, sapovirus and astrovirus as causative agents of acute viral gastroenteritis. J Virol Methods. 2007;146(1-2):36-44.

11. Wolffs PF, Bruggeman CA, van Well GT, van Loo IH. Replacing traditional diagnostics of fecal viral pathogens by a comprehensive panel of real-time PCRs. J Clin Microbiol. 2011;49(5):1926-31.

12. Sampsonas F, Kontoyiannis DP, Dickey BF, Evans SE. Performance of a standardized bronchoalveolar lavage protocol in a comprehensive cancer center: a prospective 2-year study. Cancer. 2011;117(15):3424-33.

13. Chan CC, Abi-Saleh WJ, Arroliga AC, Stillwell PC, Kirby TJ, Gordon SM, et al. Diagnostic yield and therapeutic impact of flexible bronchoscopy in lung transplant recipients. J Heart Lung Transplant. 1996;15(2):196-205.

14. Lehto JT, Anttila VJ, Lommi J, Nieminen MS, Harjula A, Taskinen E, et al. Clinical usefulness of bronchoalveolar lavage in heart transplant recipients with suspected lower respiratory tract infection. J Heart Lung Transplant. 2004;23(5):570-6.

15. Lehto JT, Koskinen PK, Anttila VJ, Lautenschlager I, Lemstrom K, Sipponen J, et al. Bronchoscopy in the diagnosis and surveillance of respiratory infections in lung and heart-lung transplant recipients. Transpl Int. 2005;18(5):562-71.

16. Palmer SM, Alexander BD, Sanders LL, Edwards LJ, Reller LB, Davis RD, et al. Significance of blood stream infection after lung transplantation: analysis in 176 consecutive patients. Transplantation. 2000;69(11):2360-6.

17. Roth A, Wiklund AE, Palsson AS, Melander EZ, Wullt M, Cronqvist $\mathrm{J}$, et al. Reducing blood culture contamination by a simple informational intervention. J Clin Microbiol. 2010;48(12):4552-8.

18. Kosmin AR, Fekete T. Use of fungal blood cultures in an academic medical center. J Clin Microbiol. 2008;46(11):3800-1.

19. Bates DW, Cook EF, Goldman L, Lee TH. Predicting bacteremia in hospitalized patients. A prospectively validated model. Ann Int Med. 1990;113(7):495-500.

20. Ramanujam P, Rathlev NK. Blood cultures do not change management in hospitalized patients with community-acquired pneumonia. Acad Emerg Med. 2006;13(7):740-5.

21. Vetter E, Torgerson C, Feuker A, Hughes J, Harmsen S, Schleck C, et al. Comparison of the BACTEC MYCO/F Lytic bottle to the isolator tube, BACTEC Plus Aerobic F/bottle, and BACTEC Anaerobic Lytic/10 bottle and comparison of the BACTEC Plus Aerobic F/bottle to the Isolator tube for recovery of bacteria, mycobacteria, and fungi from blood. J Clin Microbiol. 2001;39(12):4380-6.

22. Waite RT, Woods GL. Evaluation of BACTEC MYCO/F lytic medium for recovery of mycobacteria and fungi from blood. J Clin Microbiol. 1998;36(5):1176-9.

23. Fuller DD, Davis TE Jr, Denys GA, York MK. Evaluation of BACTEC MYCO/F Lytic medium for recovery of mycobacteria, fungi, and bacteria from blood. J Clin Microbiol. 2001;39(8):2933-6.

24. Archibald LK, McDonald LC, Addison RM, McKnight C, Byrne $\mathrm{T}$, Dobbie H, et al. Comparison of BACTEC MYCO/F LYTIC and WAMPOLE ISOLATOR 10 (lysis-centrifugation) systems for detection of bacteremia, mycobacteremia, and fungemia in a developing country. J Clin Microbiol. 2000;38(8):2994-7.

25. Creger RJ, Weeman KE, Jacobs MR, Morrissey A, Parker P, Fox $\mathrm{RM}$, et al. Lack of utility of the lysis-centrifugation blood culture method for detection of fungemia in immunocompromised cancer patients. J Clin Microbiol. 1998;36(1):290-3.

26. Berenguer J, Buck M, Witebsky F, Stock F, Pizzo PA, Walsh TJ. Lysiscentrifugation blood cultures in the detection of tissue-proven 
invasive candidiasis. Disseminated versus single-organ infection. Diagn Microbiol Infect Dis. 1993;17(2):103-9.

27. Speich R, van der Bij W. Epidemiology and management of infections after lung transplantation. Clin Infect Dis. 2001;33(Suppl 1):S58-65.

28. Hsu RB, Chang CI, Fang CT, Chang SC, Wang SS, Chu $\mathrm{SH}$. Bloodstream infection in heart transplant recipients: 12-year experience at a university hospital in Taiwan. Eur J Cardiothorac Surg. 2011;40(6):1362-7.

29. Joosten A, Maertens J, Verhaegen J, Lodewyck T, Vermeulen E, Lagrou K. High incidence of bloodstream infection detected by surveillance blood cultures in hematology patients on corticosteroid therapy. Support Care Cancer. 2012;20(11):3013-7.

30. Rodriguez L, Ethier MC, Phillips B, Lehrnbecher T, Doyle J, Sung L. Utility of peripheral blood cultures in patients with cancer and suspected blood stream infections: a systematic review. Support Care Cancer. 2012;20(12):3261-7.

31. Hummel M, Warga C, Hof H, Hehlmann R, Buchheidt D. Diagnostic yield of blood cultures from antibiotic-naive and antibiotically treated patients with haematological malignancies and high-risk neutropenia. Scand J Infect Dis. 2009;41(9):650-5.

32. Rubio M, Palau L, Vivas JR, del Potro E, Diaz-Mediavilla J, Alvarez A, et al. Predominance of gram-positive microorganisms as a cause of septicemia in patients with hematological malignancies. Infect Control Hosp Epidemiol. 1994;15(2):101-4.

33. Chitasombat MN, Kofteridis DP, Jiang Y, Tarrand J, Lewis RE, Kontoyiannis DP. Rare opportunistic (non-Candida, nonCryptococcus) yeast bloodstream infections in patients with cancer. J Infect. 2012;64(1):68-75.

34. Miceli MH, Diaz JA, Lee SA. Emerging opportunistic yeast infections. Lancet Infect Dis. 2011;11(2):142-51.

35. Duthie R, Denning DW. Aspergillus fungemia: report of two cases and review. Clin Infect Dis. 1995;20(3):598-605.

36. Reimer LG, Wilson ML, Weinstein MP. Update on detection of bacteremia and fungemia. Clin Microbiol Rev. 1997;10(3):444-65.

37. Geha DJ, Roberts GD. Laboratory detection of fungemia. Clin Lab Med. 1994;14(1):83-97.

38. Park BJ, Pappas PG, Wannemuehler KA, Alexander BD, Anaissie EJ, Andes DR, et al. Invasive non-aspergillus mold infections in transplant recipients, United States, 2001-2006. Emerg Infect Dis. 2011;17(10):1855-64.

39. Campo M, Lewis RE, Kontoyiannis DP. Invasive fusariosis in patients with hematologic malignancies at a cancer center: 19982009. J Infect. 2010;60(5):331-7.

40. Petti CA, Hassan H, Reller LB. Bloodstream infections. In: Hayden RT, Carroll KC, Tang Y-W, Wolk DM, editors. Diagnostic microbiology of the immunocompromised host. Washington, DC: ASM Press; 2009. p. 409-18.

41. Limmathurotsakul D, Jamsen K, Arayawichanont A, Simpson JA, White LJ, Lee SJ, et al. Defining the true sensitivity of culture for the diagnosis of melioidosis using Bayesian latent class models. PLoS One. 2010;5(8):e12485.

42. Charlson ES, Diamond JM, Bittinger K, Fitzgerald AS, Yadav A, Haas AR, et al. Lung-enriched organisms and aberrant bacterial and fungal respiratory microbiota following lung transplant. Am J Respir Crit Care Med. 2012;186(6):536-45.

43. Taur Y, Xavier JB, Lipuma L, Ubeda C, Goldberg J, Gobourne A, et al. Intestinal domination and the risk of bacteremia in patients undergoing allogeneic hematopoietic stem cell transplantation. Clin Infect Dis. 2012;55(7):905-14.

44. De Pauw B, Walsh TJ, Donnelly JP, Stevens DA, Edwards JE, Calandra $T$, et al. Revised definitions of invasive fungal disease from the European Organization for Research and Treatment of Cancer/Invasive Fungal Infections Cooperative Group and the National Institute of Allergy and Infectious Diseases Mycoses Study Group (EORTC/MSG) consensus group. Clin Infect Dis. 2008;46(12):1813-21.
45. Wheat LJ. Approach to the diagnosis of invasive aspergillosis and candidiasis. Clin Chest Med. 2009;30(2):367-77. viii.

46. Pfeiffer CD, Fine JP, Safdar N. Diagnosis of invasive aspergillosis using a galactomannan assay: a meta-analysis. Clin Infect Dis. 2006;42(10):1417-27.

47. Jathavedam A, Dure DC, Taur Y, Weinstock DM. Limited utility of serum galactomannan assay after auto-SCT. Bone Marrow Transplant. 2009;44(1):59-61.

48. Hachem RY, Kontoyiannis DP, Chemaly RF, Jiang Y, Reitzel R, Raad I. Utility of galactomannan enzyme immunoassay and $(1,3)$ beta-D-glucan in diagnosis of invasive fungal infections: low sensitivity for Aspergillus fumigatus infection in hematologic malignancy patients. J Clin Microbiol. 2009;47(1):129-33.

49. Marr KA, Balajee SA, McLaughlin L, Tabouret M, Bentsen C, Walsh TJ. Detection of galactomannan antigenemia by enzyme immunoassay for the diagnosis of invasive aspergillosis: variables that affect performance. J Infect Dis. 2004;190(3):641-9.

50. Nguyen MH, Leather H, Clancy CJ, Cline C, Jantz MA, Kulkarni V, et al. Galactomannan testing in bronchoalveolar lavage fluid facilitates the diagnosis of invasive pulmonary aspergillosis in patients with hematologic malignancies and stem cell transplant recipients. Biol Blood Marrow Transplant. 2011;17(7):1043-50.

51. Reinwald M, Spiess B, Heinz WJ, Vehreschild JJ, Lass-Florl C, Kiehl M, et al. Diagnosing pulmonary aspergillosis in patients with hematological malignancies: a multicenter prospective evaluation of an Aspergillus PCR assay and a galactomannan ELISA in bronchoalveolar lavage samples. Eur J Haematol. 2012;89(2):120-7.

52. Husain S, Clancy CJ, Nguyen MH, Swartzentruber S, Leather $\mathrm{H}$, LeMonte AM, et al. Performance characteristics of the platelia Aspergillus enzyme immunoassay for detection of Aspergillus galactomannan antigen in bronchoalveolar lavage fluid. Clin Vaccine Immunol. 2008;15(12):1760-3. PubMed.

53. Husain S, Paterson DL, Studer SM, Crespo M, Pilewski J, Durkin $\mathrm{M}$, et al. Aspergillus galactomannan antigen in the bronchoalveolar lavage fluid for the diagnosis of invasive aspergillosis in lung transplant recipients. Transplantation. 2007;83(10):1330-6.

54. Nguyen MH, Jaber R, Leather HL, Wingard JR, Staley B, Wheat $\mathrm{LJ}$, et al. Use of bronchoalveolar lavage to detect galactomannan for diagnosis of pulmonary aspergillosis among nonimmunocompromised hosts. J Clin Microbiol. 2007;45(9):2787-92.

55. Clancy CJ, Jaber RA, Leather HL, Wingard JR, Staley B, Wheat LJ, et al. Bronchoalveolar lavage galactomannan in diagnosis of invasive pulmonary aspergillosis among solid-organ transplant recipients. J Clin Microbiol. 2007;45(6):1759-65.

56. D'Haese J, Theunissen K, Vermeulen E, Schoemans H, De Vlieger G, Lammertijn L, et al. Detection of galactomannan in bronchoalveolar lavage fluid samples of patients at risk for invasive pulmonary aspergillosis: analytical and clinical validity. J Clin Microbiol. 2012;50(4):1258-63.

57. Tortorano AM, Esposto MC, Prigitano A, Grancini A, Ossi C, Cavanna C, et al. Cross-reactivity of Fusarium spp. in the Aspergillus Galactomannan enzyme-linked immunosorbent assay. J Clin Microbiol. 2012;50(3):1051-3.

58. Vergidis P, Razonable RR, Wheat LJ, Estes L, Caliendo AM, Baden LR, et al. Reduction in false-positive Aspergillus serum galactomannan enzyme immunoassay results associated with use of piperacillin-tazobactam in the United States. J Clin Microbiol. 2014;52(6):2199-201.

59. Lamoth F, Cruciani M, Mengoli C, Castagnola E, Lortholary O, Richardson $\mathrm{M}$, et al. beta-Glucan antigenemia assay for the diagnosis of invasive fungal infections in patients with hematological malignancies: a systematic review and meta-analysis of cohort studies from the Third European Conference on Infections in Leukemia (ECIL-3). Clin Infect Dis. 2012;54(5):633-43.

60. Karageorgopoulos DE, Vouloumanou EK, Ntziora F, Michalopoulos A, Rafailidis PI, Falagas ME. beta-D-glucan assay for the diagno- 
sis of invasive fungal infections: a meta-analysis. Clin Infect Dis 2011;52(6):750-70.

61. Racil Z, Kocmanova I, Lengerova M, Weinbergerova B, Buresova L, Toskova M, et al. Difficulties in using 1,3-\{beta\}-D-glucan as the screening test for the early diagnosis of invasive fungal infections in patients with haematological malignancies--high frequency of false-positive results and their analysis. J Med Microbiol. 2010;59(Pt 9):1016-22.

62. Costa JM, Botterel F, Cabaret O, Foulet F, Cordonnier C, Bretagne S. Association between circulating DNA, serum (1->3)-beta-Dglucan, and pulmonary fungal burden in pneumocystis pneumonia. Clin Infect Dis. 2012;55(2):e5-8.

63. de Boer MG, Gelinck LB, van Zelst BD, van de Sande WW, Willems $\mathrm{LN}$, van Dissel JT, et al. beta-D-glucan and S-adenosylmethionine serum levels for the diagnosis of pneumocystis pneumonia in HIVnegative patients: a prospective study. J Infect. 2011;62(1):93-100

64. Smith JA, Kauffman CA. Pulmonary fungal infections. Respirology. 2012;17(6):913-26.

65. Specter S, Hodinka RL, Wiedbrauk DL, Young SA. Diagnosis of viral infections. In: Richman DD, Whitley RJ, Hayden FG, editors. Clinical virology. Washington, DC: ASM Press; 2002. p. 243-72.

66. Boeckh M, Bowden RA, Goodrich JM, Pettinger M, Meyers JD. Cytomegalovirus antigen detection in peripheral blood leukocytes after allogeneic marrow transplantation. Blood. 1992;80(5):1358-64.

67. Boeckh M, Boivin G. Quantitation of cytomegalovirus: methodologic aspects and clinical applications. Clin Microbiol Rev. 1998;11(3):533-54.

68. Razonable RR, Paya CV, Smith TF. Role of the laboratory in diagnosis and management of cytomegalovirus infection in hematopoietic stem cell and solid-organ transplant recipients. J Clin Microbiol. 2002;40(3):746-52.

69. Pang XL, Chui L, Fenton J, LeBlanc B, Preiksaitis JK. Comparison of LightCycler-based PCR, COBAS amplicor CMV monitor, and pp65 antigenemia assays for quantitative measurement of cytomegalovirus viral load in peripheral blood specimens from patients after solid organ transplantation. J Clin Microbiol. 2003;41(7):3167-74.

70. Gudiol C, Garcia-Vidal C, Fernandez-Sabe N, Verdaguer R, Llado L, Roca J, et al. Clinical features and outcomes of legionnaires' disease in solid organ transplant recipients. Transpl Infect Dis. 2009;11(1):78-82.

71. Sousa D, Justo I, Dominguez A, Manzur A, Izquierdo C, Ruiz L, et al. Community-acquired pneumonia in immunocompromised older patients: incidence, causative organisms and outcome. Clin Microbiol Infect. 2013;19(2):187-92.

72. Saiki RK, Scharf S, Faloona F, Mullis KB, Horn GT, Erlich HA, et al. Enzymatic amplification of beta-globin genomic sequences and restriction site analysis for diagnosis of sickle cell anemia. Science. 1985;230(4732):1350-4.

73. Mullis KB, Faloona FA. Specific synthesis of DNA in vitro via a polymerase-catalyzed chain reaction. Methods Enzymol. 1987;155:335-50.

74. Lisby G. Application of nucleic acid amplification in clinical microbiology. Mol Biotechnol. 1999;12(1):75-99.

75. Persing DH. Diagnostic molecular microbiology. Current challenges and future directions. Diagn Microbiol Infect Dis. 1993;16(2):159-63.

76. Datta VaH RT. In vitro nucleic acid amplification. In: Persing DH, Tenover FC, Tang YW, Nolte FS, Hayden RT, Van Belkum A, editors. Molecular Microbiology. Washington, DC: ASM Press; 2011. p. 33-62.

77. Sidoti F, Bergallo M, Costa C, Cavallo R. Alternative molecular tests for virological diagnosis. Mol Biotechnol. 2013;53(3):352-62.

78. Higuchi R, Fockler C, Dollinger G, Watson R. Kinetic PCR analysis: real-time monitoring of DNA amplification reactions. Biotechnology (N Y). 1993;11(9):1026-30.
79. Higuchi R, Dollinger G, Walsh PS, Griffith R. Simultaneous amplification and detection of specific DNA sequences. Biotechnology (N Y). 1992;10(4):413-7.

80. Espy MJ, Uhl JR, Sloan LM, Buckwalter SP, Jones MF, Vetter EA, et al. Real-time PCR in clinical microbiology: applications for routine laboratory testing. Clin Microbiol Rev. 2006;19(1):165-256.

81. Cockerill FR 3rd. Application of rapid-cycle real-time polymerase chain reaction for diagnostic testing in the clinical microbiology laboratory. Arch Pathol Lab Med. 2003;127(9):1112-20.

82. Belanger SD, Boissinot M, Clairoux N, Picard FJ, Bergeron MG. Rapid detection of Clostridium difficile in feces by real-time PCR. J Clin Microbiol. 2003;41(2):730-4.

83. van den Berg RJ, Bruijnesteijn van Coppenraet LS, Gerritsen HJ, Endtz HP, van der Vorm ER, Kuijper EJ. Prospective multicenter evaluation of a new immunoassay and real-time PCR for rapid diagnosis of Clostridium difficile-associated diarrhea in hospitalized patients. J Clin Microbiol. 2005;43(10):5338-40.

84. Peterson LR, Manson RU, Paule SM, Hacek DM, Robicsek A, Thomson RB Jr, et al. Detection of toxigenic Clostridium difficile in stool samples by real-time polymerase chain reaction for the diagnosis of C. difficile-associated diarrhea. Clin Infect Dis. 2007;45(9):1152-60.

85. Sloan LM, Duresko BJ, Gustafson DR, Rosenblatt JE. Comparison of real-time PCR for detection of the tcdC gene with four toxin immunoassays and culture in diagnosis of Clostridium difficile infection. J Clin Microbiol. 2008;46(6):1996-2001.

86. Wetmur JG. DNA probes: applications of the principles of nucleic acid hybridization. Crit Rev Biochem Mol Biol. 1991;26(3-4):227-59.

87. Reisner BS, Gatson AM, Woods GL. Use of Gen-Probe AccuProbes to identify Mycobacterium avium complex, Mycobacterium tuberculosis complex, Mycobacterium kansasii, and Mycobacterium gordonae directly from BACTEC TB broth cultures. J Clin Microbiol. 1994;32(12):2995-8.

88. Peterson EM, Lu R, Floyd C, Nakasone A, Friedly G, de la Maza LM. Direct identification of Mycobacterium tuberculosis, Mycobacterium avium, and Mycobacterium intracellulare from amplified primary cultures in BACTEC media using DNA probes. $\mathrm{J}$ Clin Microbiol. 1989;27(7):1543-7.

89. Ford EG, Snead SJ, Todd J, Warren NG. Strains of Mycobacterium terrae complex which react with DNA probes for M. tuberculosis complex. J Clin Microbiol. 1993;31(10):2805-6.

90. Lim SD, Todd J, Lopez J, Ford E, Janda JM. Genotypic identification of pathogenic Mycobacterium species by using a nonradioactive oligonucleotide probe. J Clin Microbiol. 1991;29(6):1276-8.

91. Buchan BW, Ledeboer NA. Emerging technologies for the clinical microbiology laboratory. Clin Microbiol Rev. 2014;27(4):783-822.

92. von Lilienfeld-Toal M, Lehmann LE, Raadts AD, Hahn-Ast C, Orlopp KS, Marklein G, et al. Utility of a commercially available multiplex real-time PCR assay to detect bacterial and fungal pathogens in febrile neutropenia. J Clin Microbiol. 2009;47(8):2405-10.

93. Lamoth F, Jaton K, Prod'hom G, Senn L, Bille J, Calandra T, et al. Multiplex blood PCR in combination with blood cultures for improvement of microbiological documentation of infection in febrile neutropenia. J Clin Microbiol. 2010;48(10):3510-6.

94. Rath PM, Saner F, Paul A, Lehmann N, Steinmann E, Buer J, et al. Multiplex PCR for rapid and improved diagnosis of bloodstream infections in liver transplant recipients. J Clin Microbiol. 2012;50(6):2069-71.

95. Mauro MV, Cavalcanti P, Perugini D, Noto A, Sperli D, Giraldi C. Diagnostic utility of LightCycler SeptiFast and procalcitonin assays in the diagnosis of bloodstream infection in immunocompromised patients. Diagn Microbiol Infect Dis. 2012;73(4):308-11.

96. Mancini N, Clerici D, Diotti R, Perotti M, Ghidoli N, De Marco $\mathrm{D}$, et al. Molecular diagnosis of sepsis in neutropenic patients with haematological malignancies. J Med Microbiol. 2008;57(Pt 5):601-4. 
97. Janda JM, Abbott SL. 16S rRNA gene sequencing for bacterial identification in the diagnostic laboratory: pluses, perils, and pitfalls. J Clin Microbiol. 2007;45(9):2761-4.

98. Kang Y, Deng R, Wang C, Deng T, Peng P, Cheng X, et al. Etiologic diagnosis of lower respiratory tract bacterial infections using sputum samples and quantitative loop-mediated isothermal amplification. PLoS One. 2012;7(6):e38743.

99. Esteban J, Alonso-Rodriguez N, del-Prado G, Ortiz-Perez A, Molina-Manso D, Cordero-Ampuero J, et al. PCR-hybridization after sonication improves diagnosis of implant-related infection. Acta Orthop. 2012;83(3):299-304.

100. Welker M. Proteomics for routine identification of microorganisms. Proteomics. 2011;11(15):3143-53.

101. Cuenca-Estrella M, Bassetti M, Lass-Florl C, Racil Z, Richardson M, Rogers TR. Detection and investigation of invasive mould disease. J Antimicrob Chemother. 2011;66(Suppl 1):i15-24.

102. Lin MT, Lu HC, Chen WL. Improving efficacy of antifungal therapy by polymerase chain reaction-based strategy among febrile patients with neutropenia and cancer. Clin Infect Dis. 2001;33(10):1621-7.

103. Stockman L, Clark KA, Hunt JM, Roberts GD. Evaluation of commercially available acridinium ester-labeled chemiluminescent DNA probes for culture identification of Blastomyces dermatitidis, Coccidioides immitis, Cryptococcus neoformans, and Histoplasma capsulatum. J Clin Microbiol. 1993;31(4):845-50.

104. Padhye AA, Smith G, Standard PG, McLaughlin D, Kaufman L. Comparative evaluation of chemiluminescent DNA probe assays and exoantigen tests for rapid identification of Blastomyces dermatitidis and Coccidioides immitis. J Clin Microbiol. 1994;32(4):867-70.

105. Brandt ME, Gaunt D, Iqbal N, McClinton S, Hambleton S, Sigler L. False-positive Histoplasma capsulatum Gen-Probe chemiluminescent test result caused by a Chrysosporium species. J Clin Microbiol. 2005;43(3):1456-8.

106. Hall L, Le Febre KM, Deml SM, Wohlfiel SL, Wengenack NL. Evaluation of the yeast traffic light PNA FISH probes for identification of Candida species from positive blood cultures. J Clin Microbiol. 2012;50(4):1446-8.

107. Shepard JR, Addison RM, Alexander BD, Della-Latta P, Gherna M, Haase G, et al. Multicenter evaluation of the Candida albicans/ Candida glabrata peptide nucleic acid fluorescent in situ hybridization method for simultaneous dual-color identification of $\mathrm{C}$. albicans and C. glabrata directly from blood culture bottles. J Clin Microbiol. 2008;46(1):50-5.

108. Reller ME, Mallonee AB, Kwiatkowski NP, Merz WG. Use of peptide nucleic acid-fluorescence in situ hybridization for definitive, rapid identification of five common Candida species. J Clin Microbiol. 2007;45(11):3802-3.

109. Hata DJ, Buckwalter SP, Pritt BS, Roberts GD, Wengenack NL. Real-time PCR method for detection of zygomycetes. J Clin Microbiol. 2008;46(7):2353-8.

110. Innings A, Ullberg $M$, Johansson A, Rubin CJ, Noreus $N$, Isaksson $\mathrm{M}$, et al. Multiplex real-time PCR targeting the RNase P RNA gene for detection and identification of Candida species in blood. J Clin Microbiol. 2007;45(3):874-80.

111. Maaroufi Y, Heymans C, De Bruyne JM, Duchateau V, RodriguezVillalobos H, Aoun M, et al. Rapid detection of Candida albicans in clinical blood samples by using a TaqMan-based PCR assay. J Clin Microbiol. 2003;41(7):3293-8.

112. Spiess B, Buchheidt D, Baust C, Skladny H, Seifarth W, Zeilfelder $\mathrm{U}$, et al. Development of a LightCycler PCR assay for detection and quantification of Aspergillus fumigatus DNA in clinical samples from neutropenic patients. J Clin Microbiol. 2003;41(5):1811-8.

113. Suarez F, Lortholary O, Buland S, Rubio MT, Ghez D, Mahe V, et al. Detection of circulating Aspergillus fumigatus DNA by realtime PCR assay of large serum volumes improves early diagnosis of invasive aspergillosis in high-risk adult patients under hematologic surveillance. J Clin Microbiol. 2008;46(11):3772-7.

114. Landlinger C, Preuner S, Willinger B, Haberpursch B, Racil Z, Mayer J, et al. Species-specific identification of a wide range of clinically relevant fungal pathogens by use of Luminex xMAP technology. J Clin Microbiol. 2009;47(4):1063-73.

115. Mandviwala T, Shinde R, Kalra A, Sobel JD, Akins RA. Highthroughput identification and quantification of Candida species using high resolution derivative melt analysis of panfungal amplicons. J Mol Diagn. 2010;12(1):91-101.

116. Schabereiter-Gurtner C, Selitsch B, Rotter ML, Hirschl AM, Willinger B. Development of novel real-time PCR assays for detection and differentiation of eleven medically important Aspergillus and Candida species in clinical specimens. J Clin Microbiol. 2007;45(3):906-14.

117. Baskova L, Landlinger C, Preuner S, Lion T. The Pan-AC assay: a single-reaction real-time PCR test for quantitative detection of a broad range of Aspergillus and Candida species. J Med Microbiol. 2007;56(Pt 9):1167-73.

118. McTaggart LR, Wengenack NL, Richardson SE. Validation of the MycAssay pneumocystis kit for detection of pneumocystis jirovecii in bronchoalveolar lavage specimens by comparison to a laboratory standard of direct immunofluorescence microscopy, real-time PCR, or conventional PCR. J Clin Microbiol. 2012;50(6):1856-9.

119. White PL, Perry MD, Moody A, Follett SA, Morgan G, Barnes RA. Evaluation of analytical and preliminary clinical performance of Myconostica MycAssay Aspergillus when testing serum specimens for diagnosis of invasive Aspergillosis. J Clin Microbiol. 2011;49(6):2169-74.

120. Farina C, Russello G, Andreoni S, Bonetti C, Conte M, Fazi P, et al. Microarray technology for yeast identification directly from positive blood cultures. A multicenter Italian experience. Med Mycol. 2012;50(5):549-55.

121. Wengenack NL, Binnicker MJ. Fungal molecular diagnostics. Clin Chest Med. 2009;30(2):391-408. viii.

122. Hall L, Wohlfiel S, Roberts GD. Experience with the MicroSeq D2 large-subunit ribosomal DNA sequencing kit for identification of commonly encountered, clinically important yeast species. J Clin Microbiol. 2003;41(11):5099-102.

123. Hall L, Doerr KA, Wohlfiel SL, Roberts GD. Evaluation of the MicroSeq system for identification of mycobacteria by $16 \mathrm{~S}$ ribosomal DNA sequencing and its integration into a routine clinical mycobacteriology laboratory. J Clin Microbiol. 2003;41(4):1447-53.

124. Hall L, Wohlfiel S, Roberts GD. Experience with the MicroSeq D2 large-subunit ribosomal DNA sequencing kit for identification of filamentous fungi encountered in the clinical laboratory. J Clin Microbiol. 2004;42(2):622-6.

125. Hinrikson HP, Hurst SF, Lott TJ, Warnock DW, Morrison CJ. Assessment of ribosomal large-subunit D1-D2, internal transcribed spacer 1, and internal transcribed spacer 2 regions as targets for molecular identification of medically important Aspergillus species. J Clin Microbiol. 2005;43(5): 2092-103.

126. Linton CJ, Borman AM, Cheung G, Holmes AD, Szekely A, Palmer MD, et al. Molecular identification of unusual pathogenic yeast isolates by large ribosomal subunit gene sequencing: 2 years of experience at the United Kingdom mycology reference laboratory. J Clin Microbiol. 2007;45(4):1152-8.

127. Razonable RR, Eid AJ. Viral infections in transplant recipients. Minerva Med. 2009;100(6):479-501.

128. Caliendo AM, Valsamakis A, Bremer JW, Ferreira-Gonzalez A, Granger S, Sabatini L, et al. Multilaboratory evaluation of realtime PCR tests for hepatitis B virus DNA quantification. J Clin Microbiol. 2011;49(8):2854-8. 
129. Caliendo AM, Valsamakis A, Zhou Y, Yen-Lieberman B, Andersen J, Young S, et al. Multilaboratory comparison of hepatitis C virus viral load assays. J Clin Microbiol. 2006;44(5):1726-32.

130. Forman MS, Valsamakis A. Performance characteristics of a quantitative hepatitis $\mathrm{C}$ virus RNA assay using COBAS AmpliPrep total nucleic acid isolation and COBAS taqman hepatitis $\mathrm{C}$ virus analyte-specific reagent. J Mol Diagn. 2008;10(2):147-53.

131. Sloma CR, Germer JJ, Gerads TM, Mandrekar JN, Mitchell PS, Yao JD. Comparison of the Abbott realtime human immunodeficiency virus type 1 (HIV-1) assay to the Cobas AmpliPrep/Cobas TaqMan HIV-1 test: workflow, reliability, and direct costs. J Clin Microbiol. 2009;47(4):889-95.

132. Pas S, Rossen JW, Schoener D, Thamke D, Pettersson A, Babiel R, et al. Performance evaluation of the new Roche Cobas AmpliPrep/ Cobas TaqMan HIV-1 test version 2.0 for quantification of human immunodeficiency virus type 1 RNA. J Clin Microbiol. 2010;48(4):1195-200.

133. Baxter JD, Mayers DL, Wentworth DN, Neaton JD, Hoover ML, Winters MA, et al. A randomized study of antiretroviral management based on plasma genotypic antiretroviral resistance testing in patients failing therapy. CPCRA 046 study team for the Terry Beirn community programs for clinical research on AIDS. AIDS. 2000;14(9):F83-93.

134. Sturmer M, Reinheimer C. Description of two commercially available assays for genotyping of HIV-1. Intervirology. 2012;55(2):134-7.

135. Niesters HG, Zoulim F, Pichoud C, Buti M, Shapiro F, D'Heuvaert $\mathrm{N}$, et al. Validation of the INNO-LiPA HBV DR assay (version 2) in monitoring hepatitis $B$ virus-infected patients receiving nucleoside analog treatment. Antimicrob Agents Chemother. 2010;54(3):1283-9.

136. Gintowt AA, Germer JJ, Mitchell PS, Yao JD. Evaluation of the MagNA pure LC used with the TRUGENE HBV genotyping kit. J Clin Virol. 2005;34(2):155-7.

137. Germer JJ, Majewski DW, Rosser M, Thompson A, Mitchell PS, Smith TF, et al. Evaluation of the TRUGENE HCV 5'NC genotyping kit with the new GeneLibrarian module 3.1.2 for genotyping of hepatitis $\mathrm{C}$ virus from clinical specimens. J Clin Microbiol. 2003;41(10):4855-7.

138. Zekri AR, El-Din HM, Bahnassy AA, El-Shehabi AM, El-Leethy $\mathrm{H}$, Omar A, et al. TRUGENE sequencing versus INNOLiPA for sub-genotyping of HCV genotype-4. J Med Virol. 2005;75(3):412-20.

139. Caliendo AM, Shahbazian MD, Schaper C, Ingersoll J, Abdul-Ali $\mathrm{D}$, Boonyaratanakornkit $\mathrm{J}$, et al. A commutable cytomegalovirus calibrator is required to improve the agreement of viral load values between laboratories. Clin Chem. 2009;55(9):1701-10.

140. Hayden RT, Hokanson KM, Pounds SB, Bankowski MJ, Belzer SW, Carr J, et al. Multicenter comparison of different real-time PCR assays for quantitative detection of Epstein-Barr virus. J Clin Microbiol. 2008;46(1):157-63.

141. Hoffman NG, Cook L, Atienza EE, Limaye AP, Jerome KR. Marked variability of BK virus load measurement using quantitative real-time PCR among commonly used assays. J Clin Microbiol. 2008;46(8):2671-80.

142. Wolff DJ, Heaney DL, Neuwald PD, Stellrecht KA, Press RD. Multi-site PCR-based CMV viral load assessment-assays demonstrate linearity and precision, but lack numeric standardization: a report of the association for molecular pathology. J Mol Diagn. 2009;11(2):87-92.

143. Pang XL, Fox JD, Fenton JM, Miller GG, Caliendo AM, Preiksaitis JK. Interlaboratory comparison of cytomegalovirus viral load assays. Am J Transplant. 2009;9(2):258-68.

144. Preiksaitis JK, Pang XL, Fox JD, Fenton JM, Caliendo AM, Miller GG. Interlaboratory comparison of epstein-barr virus viral load assays. Am J Transplant. 2009;9(2):269-79.
145. Kraft CS, Armstrong WS, Caliendo AM. Interpreting quantitative cytomegalovirus DNA testing: understanding the laboratory perspective. Clin Infect Dis. 2012;54(12):1793-7.

146. Fryer JF, Heath AB AR, Minor PD and the collaborative study group. Collaborative study to evaluate the proposed 1st WHO International Standard for human cytomegalovirus (HCMV) for nucleic acid amplification (NAT)-based assays. 2010 Contract No.: WHO/BS/10.2138.

147. Fryer JF HA, Wilkinson DE, Minor PD and the collaborative study group. Collaborative study to evaluate the proposed 1st WHO International Standard for Epstein-Barr virus (EBV) for nucleic acid amplification (NAT)-based assays. 2011 Contract No.: WHO/ BS/11.2172.

148. Hayden RT, Sun Y, Tang L, Procop GW, Hillyard DR, Pinsky BA, et al. Progress in quantitative viral load testing: variability and impact of the WHO quantitative international standards. J Clin Microbiol. 2017;55(2):423-30.

149. Drew WL. Cytomegalovirus resistance testing: pitfalls and problems for the clinician. Clin Infect Dis. 2010;50(5):733-6.

150. Ginocchio CC, Zhang F, Manji R, Arora S, Bornfreund M, Falk $\mathrm{L}$, et al. Evaluation of multiple test methods for the detection of the novel 2009 influenza A (H1N1) during the New York City outbreak. J Clin Virol. 2009;45(3):191-5.

151. Ginocchio CC, St George K. Likelihood that an unsubtypeable influenza A virus result obtained with the Luminex xTAG respiratory virus panel is indicative of infection with novel A/ H1N1 (swine-like) influenza virus. J Clin Microbiol. 2009;47(7): 2347-8.

152. Hayden RT, Gu Z, Rodriguez A, Tanioka L, Ying C, Morgenstern $\mathrm{M}$, et al. Comparison of two broadly multiplexed PCR systems for viral detection in clinical respiratory tract specimens from immunocompromised children. J Clin Virol. 2012;53(4):308-13.

153. Babady NE, Mead P, Stiles J, Brennan C, Li H, Shuptar S, et al. Comparison of the Luminex XTAG RVP fast assay and the Idaho technology FilmArray RP assay for detection of respiratory viruses in pediatric patients at a cancer hospital. J Clin Microbiol. 2012;50(7):2282-8.

154. Sanghavi SK, Bullotta A, Husain S, Rinaldo CR. Clinical evaluation of multiplex real-time PCR panels for rapid detection of respiratory viral infections. J Med Virol. 2012;84(1):162-9.

155. Gadsby NJ, Hardie A, Claas EC, Templeton KE. Comparison of the Luminex respiratory virus panel fast assay with in-house real-time PCR for respiratory viral infection diagnosis. J Clin Microbiol. 2010;48(6):2213-6.

156. Loeffelholz MJ, Pong DL, Pyles RB, Xiong Y, Miller AL, Bufton $\mathrm{KK}$, et al. Comparison of the FilmArray respiratory panel and Prodesse real-time PCR assays for detection of respiratory pathogens. J Clin Microbiol. 2011;49(12):4083-8.

157. Murali S, Langston AA, Nolte FS, Banks G, Martin R, Caliendo AM. Detection of respiratory viruses with a multiplex polymerase chain reaction assay (MultiCode-PLx respiratory virus panel) in patients with hematologic malignancies. Leuk Lymphoma. 2009;50(4):619-24.

158. Alby K, Popowitch EB, Miller MB. Comparative evaluation of the Nanosphere Verigene RV+ assay with the Simplexa Flu A/B \& RSV kit for the detection of influenza and respiratory syncytial viruses. J Clin Microbiol. 2013;51(1):352-3. Epub 2012 Nov 14.

159. Selvaraju SB, Selvarangan R. Evaluation of three influenza A and B real-time reverse transcription-PCR assays and a new 2009 H1N1 assay for detection of influenza viruses. J Clin Microbiol. 2010;48(11):3870-5.

160. Robert-Gangneux F, Darde ML. Epidemiology of and diagnostic strategies for toxoplasmosis. Clin Microbiol Rev. 2012;25(2):264-96.

161. Patrat-Delon S, Gangneux JP, Lavoue S, Lelong B, Guiguen C, le Tulzo Y, et al. Correlation of parasite load determined by quantitative 
PCR to clinical outcome in a heart transplant patient with disseminated toxoplasmosis. J Clin Microbiol. 2010;48(7):2541-5.

162. Li L, Mahan CS, Palaci M, Horter L, Loeffelholz L, Johnson JL, et al. Sputum Mycobacterium tuberculosis mRNA as a marker of bacteriologic clearance in response to antituberculosis therapy. J Clin Microbiol. 2010;48(1):46-51.

163. Mdivani N, Li H, Akhalaia M, Gegia M, Goginashvili L, Kernodle DS, et al. Monitoring therapeutic efficacy by real-time detection of Mycobacterium tuberculosis mRNA in sputum. Clin Chem. 2009;55(9):1694-700.

164. Gaydos CA, Howell MR, Quinn TC, Gaydos JC, McKee KT Jr. Use of ligase chain reaction with urine versus cervical culture for detection of Chlamydia trachomatis in an asymptomatic military population of pregnant and nonpregnant females attending Papanicolaou smear clinics. J Clin Microbiol. 1998;36(5):1300-4.

165. Morre SA, Sillekens PT, Jacobs MV, de Blok S, Ossewaarde JM, van Aarle $\mathrm{P}$, et al. Monitoring of Chlamydia trachomatis infections after antibiotic treatment using RNA detection by nucleic acid sequence based amplification. Mol Pathol. 1998;51(3):149-54.

166. Aellen S, Que YA, Guignard B, Haenni M, Moreillon P. Detection of live and antibiotic-killed bacteria by quantitative real-time PCR of specific fragments of rRNA. Antimicrob Agents Chemother. 2006;50(6):1913-20.

167. Desjardin LE, Perkins MD, Wolski K, Haun S, Teixeira L, Chen Y, et al. Measurement of sputum Mycobacterium tuberculosis messenger RNA as a surrogate for response to chemotherapy. Am J Resp Crit Care Med. 1999;160(1):203-10.

168. Eltringham IJ, Drobniewski FA, Mangan JA, Butcher PD, Wilson SM. Evaluation of reverse transcription-PCR and a bacteriophagebased assay for rapid phenotypic detection of rifampin resistance in clinical isolates of Mycobacterium tuberculosis. J Clin Microbiol. 1999;37(11):3524-7.

169. Hu Y, Mangan JA, Dhillon J, Sole KM, Mitchison DA, Butcher PD, et al. Detection of mRNA transcripts and active transcription in persistent Mycobacterium tuberculosis induced by exposure to rifampin or pyrazinamide. J Bacteriol. 2000;182(22):6358-65.

170. Jou NT, Yoshimori RB, Mason GR, Louie JS, Liebling MR. Single-tube, nested, reverse transcriptase PCR for detection of viable Mycobacterium tuberculosis. J Clin Microbiol. 1997;35(5):1161-5.

171. Sotlar K, Stubner A, Diemer D, Menton S, Menton M, Dietz K, et al. Detection of high-risk human papillomavirus E6 and E7 oncogene transcripts in cervical scrapes by nested RT-polymerase chain reaction. J Med Virol. 2004;74(1):107-16.

172. Szarewski A, Ambroisine L, Cadman L, Austin J, Ho L, Terry G, et al. Comparison of predictors for high-grade cervical intraepithelial neoplasia in women with abnormal smears. Cancer Epidemiol Biomark Prev. 2008;17(11):3033-42.

173. Nagalakshmi U, Wang Z, Waern K, Shou C, Raha D, Gerstein M, et al. The transcriptional landscape of the yeast genome defined by RNA sequencing. Science. 2008;320(5881):1344-9.

174. Phattarasukol S, Radey MC, Lappala CR, Oda Y, Hirakawa H, Brittnacher MJ, et al. Identification of a p-coumarate degradation regulon in Rhodopseudomonas palustris using Xpression, an integrated tool for prokaryotic RNA-seq data processing. Appl Environ Microbiol. 2012;13:13.

175. Law GL, Korth MJ, Benecke AG, Katze MG. Systems virology: host-directed approaches to viral pathogenesis and drug targeting. Nat Rev Microbiol. 2013;11(7):455-66.

176. Hebecker B, Vlaic S, Conrad T, Bauer M, Brunke S, Kapitan M, et al. Dual-species transcriptional profiling during systemic candidiasis reveals organ-specific host-pathogen interactions. Sci Rep. 2016;6:36055.

177. Rasmussen AL, Tchitchek N, Susnow NJ, Krasnoselsky AL, Diamond DL, Yeh MM, et al. Early transcriptional programming links progression to hepatitis $\mathrm{C}$ virus-induced severe liver disease in transplant patients. Hepatology (Baltimore, Md). 2012;56(1):17-27.

178. Ko G, Cromeans TL, Sobsey MD. Detection of infectious adenovirus in cell culture by mRNA reverse transcription-PCR. Appl Environ Microbiol. 2003;69(12):7377-84.

179. Wang G, Barton C, Rodgers FG. Bacterial DNA decontamination for reverse transcription polymerase chain reaction (RT-PCR). J Microbiol Methods. 2002;51(1):119-21.

180. Chen Y, Klein JR, McKay LL, Dunny GM. Quantitative analysis of group II intron expression and splicing in Lactococcus lactis. Appl Environ Microbiol. 2005;71(5):2576-86.

181. Cricca M, Venturoli S, Leo E, Costa S, Musiani M, Zerbini M. Molecular analysis of HPV 16 E6I/E6II spliced mRNAs and correlation with the viral physical state and the grade of the cervical lesion. J Med Virol. 2009;81(7):1276-82.

182. Parshionikar S, Laseke I, Fout GS. Use of propidium monoazide in reverse transcriptase PCR to distinguish between infectious and noninfectious enteric viruses in water samples. Appl Environ Microbiol. 2010;76(13):4318-26.

183. Pholwat S, Heysell S, Stroup S, Foongladda S, Houpt E. Rapid first- and second-line drug susceptibility assay for Mycobacterium tuberculosis isolates by use of quantitative PCR. J Clin Microbiol. 2011;49(1):69-75.

184. Fenselau C, Demirev PA. Characterization of intact microorganisms by MALDI mass spectrometry. Mass Spectrom Rev. 2001;20(4):157-71.

185. Holland RD, Wilkes JG, Rafii F, Sutherland JB, Persons CC, Voorhees KJ, et al. Rapid identification of intact whole bacteria based on spectral patterns using matrix-assisted laser desorption/ ionization with time-of-flight mass spectrometry. Rapid Commun Mass Spectrom. 1996;10(10):1227-32.

186. Krishnamurthy T, Ross PL, Rajamani U. Detection of pathogenic and non-pathogenic bacteria by matrix-assisted laser desorption/ ionization time-of-flight mass spectrometry. Rapid Commun Mass Spectrom. 1996;10(8):883-8.

187. Bizzini A, Greub G. Matrix-assisted laser desorption ionization time-of-flight mass spectrometry, a revolution in clinical microbial identification. Clin Microbiol Infect. 2010;16(11):1614-9.

188. Croxatto A, Prod'hom G, Greub G. Applications of MALDI-TOF mass spectrometry in clinical diagnostic microbiology. FEMS Microbiol Rev. 2012;36(2):380-407.

189. Seng P, Drancourt M, Gouriet F, La Scola B, Fournier PE, Rolain $\mathrm{JM}$, et al. Ongoing revolution in bacteriology: routine identification of bacteria by matrix-assisted laser desorption ionization timeof-flight mass spectrometry. Clin Infect Dis. 2009;49(4):543-51.

190. He Y, Li H, Lu X, Stratton CW, Tang YW. Mass spectrometry biotyper system identifies enteric bacterial pathogens directly from colonies grown on selective stool culture media. J Clin Microbiol. 2010;48(11):3888-92.

191. Cherkaoui A, Hibbs J, Emonet S, Tangomo M, Girard M, Francois $\mathrm{P}$, et al. Comparison of two matrix-assisted laser desorption ionization-time of flight mass spectrometry methods with conventional phenotypic identification for routine identification of bacteria to the species level. J Clin Microbiol. 2010;48(4):1169-75.

192. Marko DC, Saffert RT, Cunningham SA, Hyman J, Walsh J, Arbefeville S, et al. Evaluation of the Bruker Biotyper and Vitek MS matrix-assisted laser desorption ionization-time of flight mass spectrometry systems for identification of nonfermenting gramnegative bacilli isolated from cultures from cystic fibrosis patients. J Clin Microbiol. 2012;50(6):2034-9.

193. Loonen AJ, Jansz AR, Bergland JN, Valkenburg M, Wolffs PF, van den Brule AJ. Comparative study using phenotypic, genotypic, and proteomics methods for identification of coagulase-negative staphylococci. J Clin Microbiol. 2012;50(4):1437-9.

194. Ferreira L, Sanchez-Juanes F, Guerra IP, Garcia Garcia MI, Sanchez JE, Gonzalez-Buitrago JM, et al. Microorganisms direct 
identification from blood culture by Maldi-Tof mass spectrometry. Clin Microbiol Infect. 2011;17(4):546-51.

195. Ferroni A, Suarez S, Beretti JL, Dauphin B, Bille E, Meyer J, et al. Real-time identification of bacteria and Candida species in positive blood culture broths by matrix-assisted laser desorption ionization-time of flight mass spectrometry. J Clin Microbiol. 2010;48(5):1542-8.

196. La Scola B, Raoult D. Direct identification of bacteria in positive blood culture bottles by matrix-assisted laser desorption ionisation time-of-flight mass spectrometry. PLoS One. 2009;4(11):e8041.

197. Yan Y, He Y, Maier T, Quinn C, Shi G, Li H, et al. Improved identification of yeast species directly from positive blood culture media by combining Sepsityper specimen processing and microflex analysis with the matrix-assisted laser desorption ionization Biotyper system. J Clin Microbiol. 2011;49(7):2528-32.

198. Schlebusch S, Price GR, Hinds S, Nourse C, Schooneveldt JM, Tilse MH, et al. First outbreak of PVL-positive nonmultiresistant MRSA in a neonatal ICU in Australia: comparison of MALDITOF and SNP-plus-binary gene typing. Eur J Clin Microbiol Infect Dis. 2010;29(10):1311-4.

199. Wolters M, Rohde H, Maier T, Belmar-Campos C, Franke G, Scherpe S, et al. MALDI-TOF MS fingerprinting allows for discrimination of major methicillin-resistant Staphylococcus aureus lineages. Int J Med Microbiol. 2011;301(1):64-8

200. Du Z, Yang R, Guo Z, Song Y, Wang J. Identification of Staphylococcus aureus and determination of its methicillin resistance by matrix-assisted laser desorption/ionization time-of-flight mass spectrometry. Anal Chem. 2002;74(21):5487-91.

201. Griffin PM, Price GR, Schooneveldt JM, Schlebusch S, Tilse MH, Urbanski T, et al. The use of MALDI-TOF MS to identify vancomycin resistant enterococci and investigate the epidemiology of an outbreak. J Clin Microbiol. 2012;27:27.

202. Hrabak J, Walkova R, Studentova V, Chudackova E, Bergerova T. Carbapenemase activity detection by matrix-assisted laser desorption ionization-time of flight mass spectrometry. J Clin Microbiol. 2011:49(9):3222-7.

203. Bittar F, Ouchenane Z, Smati F, Raoult D, Rolain JM. MALDITOF-MS for rapid detection of staphylococcal Panton-valentine leukocidin. Int J Antimicrob Agents. 2009;34(5):467-70.

204. Burckhardt I, Zimmermann S. Using matrix-assisted laser desorption ionization-time of flight mass spectrometry to detect carbapenem resistance within 1 to 2.5 hours. J Clin Microbiol 2011;49(9):3321-4.

205. Hrabak J, Studentova V, Walkova R, Zemlickova H, Jakubu V, Chudackova E, et al. Detection of NDM-1, VIM-1, KPC, OXA-48, and OXA-162 carbapenemases by matrix-assisted laser desorption ionization-time of flight mass spectrometry. J Clin Microbiol. 2012;50(7):2441-3

206. Kempf M, Bakour S, Flaudrops C, Berrazeg M, Brunel JM, Drissi $\mathrm{M}$, et al. Rapid detection of carbapenem resistance in Acinetobacter baumannii using matrix-assisted laser desorption ionization-time of flight mass spectrometry. PLoS One. 2012;7(2):e31676.

207. Sparbier K, Schubert S, Weller U, Boogen C, Kostrzewa M. Matrix-assisted laser desorption ionization-time of flight mass spectrometry-based functional assay for rapid detection of resistance against beta-lactam antibiotics. J Clin Microbiol. 2012;50(3):927-37.

208. Simon L, Gauvin F, Amre DK, Saint-Louis P, Lacroix J. Serum procalcitonin and $\mathrm{C}$-reactive protein levels as markers of bacterial infection: a systematic review and meta-analysis. Clin Infect Dis. 2004;39(2):206-17.

209. Sandkovsky U, Kalil AC, Florescu DF. The use and value of procalcitonin in solid organ transplantation. Clin Transpl. 2015;29(8):689-96.

210. Yu XY, Wang Y, Zhong H, Dou QL, Song YL, Wen H. Diagnostic value of serum procalcitonin in solid organ transplant recipi- ents: a systematic review and meta-analysis. Transplant Proc. 2014;46(1):26-32.

211. van Houten CB, de Groot JA, Klein A, Srugo I, Chistyakov I, de Waal W, et al. A host-protein based assay to differentiate between bacterial and viral infections in preschool children (OPPORTUNITY): a double-blind, multicentre, validation study. Lancet Infect Dis. 2017;17(4):431-40.

212. Kaluzna-Czaplinska J. Current medical research with the application of coupled techniques with mass spectrometry. Med Sci Monit. 2011;17(5):RA117-23.

213. Gibreel TM, Dodgson AR, Cheesbrough J, Bolton FJ, Fox AJ, Upton M. High metabolic potential may contribute to the success of ST131uropathogenicEscherichia coli. J Clin Microbiol. 2012;18:18.

214. Chambers ST, Bhandari S, Scott-Thomas A, Syhre M. Novel diagnostics: progress toward a breath test for invasive Aspergillus fumigatus. Med Mycol. 2011;49(Suppl 1):S54-61. Epub 2010 Aug 26.

215. Zechman JM, Aldinger S, Labows JN Jr. Characterization of pathogenic bacteria by automated headspace concentration-gas chromatography. J Chromatogr. 1986;377:49-57.

216. Labows JN, McGinley KJ, Webster GF, Leyden JJ. Headspace analysis of volatile metabolites of Pseudomonas aeruginosa and related species by gas chromatography-mass spectrometry. J Clin Microbiol. 1980;12(4):521-6.

217. Gao P, Korley F, Martin J, Chen BT. Determination of unique microbial volatile organic compounds produced by five Aspergillus species commonly found in problem buildings. AIHA J (Fairfax, Va). 2002;63(2):135-40.

218. Syhre M, Scotter JM, Chambers ST. Investigation into the production of 2-Pentylfuran by Aspergillus fumigatus and other respiratory pathogens in vitro and human breath samples. Med Mycol. 2008;46(3):209-15.

219. Koo S, Thomas HR, Daniels SD, Lynch RC, Fortier SM, Shea $\mathrm{MM}$, et al. A breath fungal secondary metabolite signature to diagnose invasive aspergillosis. Clin Infect Dis. 2014;59(12):1733-40.

220. Syhre M, Manning L, Phuanukoonnon S, Harino P, Chambers ST. The scent of Mycobacterium tuberculosis--part II breath. Tuberculosis (Edinb). 2009;89(4):263-6.

221. Gooley TA, Chien JW, Pergam SA, Hingorani S, Sorror ML, Boeckh M, et al. Reduced mortality after allogeneic hematopoieticcell transplantation. N Engl J Med. 2010;363(22):2091-101.

222. Slavin S, Nagler A, Naparstek E, Kapelushnik Y, Aker M, Cividalli $\mathrm{G}$, et al. Nonmyeloablative stem cell transplantation and cell therapy as an alternative to conventional bone marrow transplantation with lethal cytoreduction for the treatment of malignant and nonmalignant hematologic diseases. Blood. 1998;91(3):756-63.

223. Ponce DM, Zheng J, Gonzales AM, Lubin M, Heller G, CastroMalaspina $\mathrm{H}$, et al. Reduced late mortality risk contributes to similar survival after double-unit cord blood transplantation compared with related and unrelated donor hematopoietic stem cell transplantation. Biol Blood Marrow Transplant. 2011;17(9):1316-26.

224. Confer DL, Abress LK, Navarro W, Madrigal A. Selection of adult unrelated hematopoietic stem cell donors: beyond HLA. Biol Blood Marrow Transplant. 2010;16(1 Suppl):S8-S11.

225. Pergam SA, Xie H, Sandhu R, Pollack M, Smith J, Stevens-Ayers $\mathrm{T}$, et al. Efficiency and risk factors for CMV transmission in seronegative hematopoietic stem cell recipients. Biol Blood Marrow Transplant. 2012;18(9):1391-400.

226. Meij P, Jedema I, Zandvliet ML, van der Heiden PL, van de Meent M, van Egmond HM, et al. Effective treatment of refractory CMV reactivation after allogeneic stem cell transplantation with in vitro-generated CMV pp65-specific CD8+ T-cell lines. J Immunother. 2012;35(8):621-8.

227. Boeckh M, Ljungman P. How we treat cytomegalovirus in hematopoietic cell transplant recipients. Blood. 2009;113(23):5711-9. 
228. Milano F, Pergam SA, Xie H, Leisenring WM, Gutman JA, Riffkin I, et al. Intensive strategy to prevent CMV disease in seropositive umbilical cord blood transplant recipients. Blood. 2011;118(20):5689-96.

229. Meers S, Lagrou K, Theunissen K, Dierickx D, Delforge M, Devos T, et al. Myeloablative conditioning predisposes patients for toxoplasma gondii reactivation after allogeneic stem cell transplantation. Clin Infect Dis. 2010;50(8):1127-34.

230. Veltrop-Duits LA, van Vreeswijk T, Heemskerk B, Thijssen JC, El Seady R, Jol-van der Zijde EM, et al. High titers of pre-existing adenovirus serotype-specific neutralizing antibodies in the host predict viral reactivation after allogeneic stem cell transplantation in children. Clin Infect Dis. 2011;52(12):1405-13.

231. Moon SM, Lee SO, Choi SH, Kim YS, Woo JH, Yoon DH, et al. Comparison of the QuantiFERON-TB gold in-tube test with the tuberculin skin test for detecting latent tuberculosis infection prior to hematopoietic stem cell transplantation. Transpl Infect Dis. 2013;15:104-9. Epub 2012 Jul 23.

232. Wirk B, Wingard JR. Strongyloides stercoralis hyperinfection in hematopoietic stem cell transplantation. Transpl Infect Dis. 2009;11(2):143-8.

233. Bogdanovic G, Ljungman P, Wang F, Dalianis T. Presence of human polyomavirus DNA in the peripheral circulation of bone marrow transplant patients with and without hemorrhagic cystitis. Bone Marrow Transplant. 1996;17(4):573-6.

234. Boeckh M, Geballe AP. Cytomegalovirus: pathogen, paradigm, and puzzle. J Clin Invest. 2011;121(5):1673-80.

235. Boeckh M. Complications, diagnosis, management, and prevention of CMV infections: current and future. ASH Education Program Book. 2011;2011:305-9.

236. Kotton CN, Kumar D, Caliendo AM, Asberg A, Chou S, DanzigerIsakov $\mathrm{L}$, et al. Updated international consensus guidelines on the management of cytomegalovirus in solid-organ transplantation. Transplantation. 2013;96(4):333-60.

237. Tomblyn M, Chiller T, Einsele H, Gress R, Sepkowitz K, Storek $\mathrm{J}$, et al. Guidelines for preventing infectious complications among hematopoietic cell transplantation recipients: a global perspective. Biol Blood Marrow Transplant. 2009;15(10):1143-238.

238. Green ML, Leisenring W, Stachel D, Pergam SA, Sandmaier BM, Wald A, et al. Efficacy of a viral load-based, risk-adapted, preemptive treatment strategy for prevention of cytomegalovirus disease after hematopoietic cell transplantation. Biol Blood Marrow Transplant. 2012;18(11):1687-99.

239. Hayden RT, Preiksaitis J, Tong Y, Pang X, Sun Y, Tang L, et al. Commutability of the first World Health Organization international standard for human cytomegalovirus. J Clin Microbiol. 2015;53(10):3325-33.

240. Cottler-Fox M, Lynch M, Deeg HJ, Koss LG. Human polyomavirus: lack of relationship of viruria to prolonged or severe hemorrhagic cystitis after bone marrow transplant. Bone Marrow Transplant. 1989;4(3):279-82.

241. Hirsch HH. BK virus: opportunity makes a pathogen. Clin Infect Dis. 2005;41(3):354-60.

242. Burbach M, Birsen R, Denis B, Munier AL, Verine J, de Fontbrune $\mathrm{FS}$, et al. A case of BK virus nephropathy without hemorrhagic cystitis after hematopoietic stem cell transplantation. Ann Hematol. 2016;95(9):1567-8.

243. Papanicolaou GA, Lee YJ, Young JW, Seshan SV, Boruchov AM, Chittick G, et al. Brincidofovir for polyomavirus-associated nephropathy after allogeneic hematopoietic stem cell transplantation. Am J Kidney Dis. 2015;65(5):780-4.

244. Raval M, Gulbis A, Bollard C, Leen A, Chemaly R, Shpall E, et al. Evaluation and management of BK virus-associated nephropathy following allogeneic hematopoietic cell transplantation. Biol Blood Marrow Transplant. 2011;17(11):1589-93.
245. Bedi A, Miller CB, Hanson JL, Goodman S, Ambinder RF, Charache $\mathrm{P}$, et al. Association of BK virus with failure of prophylaxis against hemorrhagic cystitis following bone marrow transplantation. J Clin Oncol. 1995;13(5):1103-9.

246. Cesaro S, Facchin C, Tridello G, Messina C, Calore E, Biasolo MA, et al. A prospective study of BK-virus-associated haemorrhagic cystitis in paediatric patients undergoing allogeneic haematopoietic stem cell transplantation. Bone Marrow Transplant. 2008;41(4):363-70.

247. Imperiale MJ. The human polyomaviruses, BKV and JCV: molecular pathogenesis of acute disease and potential role in cancer. Virology. 2000;267(1):1-7.

248. Rabenau HF, Preiser W, Franck S, Schwerdtfeger S, Doerr HW. Polyomavirus viruria in bone marrow transplant recipients: lack of correlation with clinical symptoms. Infection. 2002;30(2):91-3.

249. Tomonari A, Takahashi S, Ooi J, Fukuno K, Takasugi K, Tsukada $\mathrm{N}$, et al. Hemorrhagic cystitis in adults after unrelated cord blood transplantation: a single-institution experience in Japan. Int $\mathbf{J}$ Hematol. 2006;84(3):268-71.

250. Erard V, Kim HW, Corey L, Limaye A, Huang ML, Myerson D, et al. BK DNA viral load in plasma: evidence for an association with hemorrhagic cystitis in allogeneic hematopoietic cell transplant recipients. Blood. 2005;106(3):1130-2.

251. Erard V, Storer B, Corey L, Nollkamper J, Huang ML, Limaye A, et al. BK virus infection in hematopoietic stem cell transplant recipients: frequency, risk factors, and association with postengraftment hemorrhagic cystitis. Clin Infect Dis. 2004;39(12):1861-5.

252. Lee YJ, Zheng J, Kolitsopoulos Y, Chung D, Amigues I, Son T, et al. Relationship of BK polyoma virus (BKV) in the urine with hemorrhagic cystitis and renal function in recipients of $\mathrm{T}$ celldepleted peripheral blood and cord blood stem cell transplantations. Biol Blood Marrow Transplant. 2014;20(8):1204-10.

253. Leung AY, Chan MT, Yuen KY, Cheng VC, Chan KH, Wong CL, et al. Ciprofloxacin decreased polyoma BK virus load in patients who underwent allogeneic hematopoietic stem cell transplantation. Clin Infect Dis. 2005;40(4):528-37.

254. Leung AY, Suen CK, Lie AK, Liang RH, Yuen KY, Kwong YL. Quantification of polyoma BK viruria in hemorrhagic cystitis complicating bone marrow transplantation. Blood. 2001;98(6):1971-8.

255. Randhawa PS, Popescu I, Macedo C, Zeevi A, Shapiro R, Vats AN, et al. Detection of CD8+ T cells sensitized to BK virus large $\mathrm{T}$ antigen in healthy volunteers and kidney transplant recipients. Hum Immunol. 2006;67(4-5):298-302.

256. Andrei G, Snoeck R, Vandeputte M, De Clercq E. Activities of various compounds against murine and primate polyomaviruses. Antimicrob Agents Chemother. 1997;41(3):587-93.

257. Bridges B, Donegan S, Badros A. Cidofovir bladder instillation for the treatment of BK hemorrhagic cystitis after allogeneic stem cell transplantation. Am J Hematol. 2006;81(7):535-7.

258. Ferrazzi E, Peracchi M, Biasolo MA, Faggionato O, Stefanelli S, Palu G. Antiviral activity of gyrase inhibitors norfloxacin, coumermycin A1 and nalidixic acid. Biochem Pharmacol. 1988;37(9):1885-6.

259. Portolani M, Pietrosemoli P, Cermelli C, Mannini-Palenzona A, Grossi MP, Paolini L, et al. Suppression of BK virus replication and cytopathic effect by inhibitors of prokaryotic DNA gyrase. Antivir Res. 1988;9(3):205-18.

260. Savona MR, Newton D, Frame D, Levine JE, Mineishi S, Kaul DR. Low-dose cidofovir treatment of BK virus-associated hemorrhagic cystitis in recipients of hematopoietic stem cell transplant. Bone Marrow Transplant. 2007;39(12):783-7.

261. Walden O, Hartel C, Doehn C, Jocham D. Intravesical cidofovir--instillation therapy for polyomavirus-associated hemorrhagic cystitis after bone marrow transplantation. Urologe A. 
2007;46(5):535-7. Intravesikale Cidofovir--Instillationstherapie bei Polyomavirus-assoziierter hamorrhagischer Zystitis nach Knochenmarktransplantation. ger.

262. Wong AS, Chan KH, Cheng VC, Yuen KY, Kwong YL, Leung AY. Relationship of pretransplantation polyoma BK virus serologic findings and BK viral reactivation after hematopoietic stem cell transplantation. Clin Infect Dis. 2007;44(6):830-7.

263. Lee YJ, Palomino-Guilen P, Babady NE, Lamson DM, St George $\mathrm{K}$, Tang YW, et al. Disseminated adenovirus infection in cancer patients presenting with focal pulmonary consolidation. J Clin Microbiol. 2014;52(1):350-3.

264. Rustia E, Violago L, Jin Z, Foca MD, Kahn JM, Arnold S, et al. Risk factors and utility of a risk-based algorithm for monitoring cytomegalovirus, Epstein-Barr virus, and adenovirus infections in pediatric recipients after allogeneic hematopoietic cell transplantation. Biol Blood Marrow Transplant. 2016;22(9):1646-53.

265. Sive JI, Thomson KJ, Morris EC, Ward KN, Peggs KS. Adenoviremia has limited clinical impact in the majority of patients following alemtuzumab-based allogeneic stem cell transplantation in adults. Clin Infect Dis. 2012;55(10):1362-70.

266. Flomenberg P, Babbitt J, Drobyski WR, Ash RC, Carrigan DR, Sedmak GV, et al. Increasing incidence of adenovirus disease in bone marrow transplant recipients. J Infect Dis. 1994;169(4):775-81.

267. Symeonidis N, Jakubowski A, Pierre-Louis S, Jaffe D, Pamer E, Sepkowitz K, et al. Invasive adenoviral infections in T-cell-depleted allogeneic hematopoietic stem cell transplantation: high mortality in the era of cidofovir. Transpl Infect Dis. 2007;9(2):108-13.

268. Howard DS, Phillips IG, Reece DE, Munn RK, Henslee-Downey $\mathrm{J}$, Pittard M, et al. Adenovirus infections in hematopoietic stem cell transplant recipients. Clin Infect Dis. 1999;29(6):1494-501.

269. Lynch JP 3rd, Kajon AE. Adenovirus: epidemiology, global spread of novel serotypes, and advances in treatment and prevention. Sem Resp Crit Care Med. 2016;37(4):586-602.

270. Boeckh M, Gooley TA, Myerson D, Cunningham T, Schoch G, Bowden RA. Cytomegalovirus pp65 antigenemia-guided early treatment with ganciclovir versus ganciclovir at engraftment after allogeneic marrow transplantation: a randomized double-blind study. Blood. 1996;88(10):4063-71.

271. Zaia JA. Prevention of cytomegalovirus disease in hematopoietic stem cell transplantation. Clin Infect Dis. 2002;35(8):999-1004.

272. Lindemans CA, Leen AM, Boelens JJ. How I treat adenovirus in hematopoietic stem cell transplant recipients. Blood. 2010;116(25):5476-85.

273. Matthes-Martin S, Feuchtinger T, Shaw PJ, Engelhard D, Hirsch $\mathrm{HH}$, Cordonnier C, Ljungman P, Fourth European Conference on Infections in Leukemia. European guidelines for diagnosis and treatment of adenovirus infection in leukemia and stem cell transplantation: summary of ECIL-4 (2011). Transpl Infect Dis. 2012;14(6):555-63.

274. Williams KM, Agwu AL, Dabb AA, Higman MA, Loeb DM, Valsamakis A, et al. A clinical algorithm identifies high risk pediatric oncology and bone marrow transplant patients likely to benefit from treatment of adenoviral infection. J Pediatr Hematol Oncol. 2009;31(11):825-31.

275. Zaia J, Baden L, Boeckh MJ, Chakrabarti S, Einsele H, Ljungman $\mathrm{P}$, et al. Viral disease prevention after hematopoietic cell transplantation. Bone Marrow Transplant. 2009;44(8):471-82.

276. Ohrmalm L, Lindblom A, Omar H, Norbeck O, Gustafson I, Lewensohn-Fuchs I, et al. Evaluation of a surveillance strategy for early detection of adenovirus by PCR of peripheral blood in hematopoietic SCT recipients: incidence and outcome. Bone Marrow Transplant. 2011;46(2):267-72.

277. Ganzenmueller T, Buchholz S, Harste G, Dammann E, Trenschel R, Heim A. High lethality of human adenovirus disease in adult allogeneic stem cell transplant recipients with high adenoviral blood load. J Clin Virol. 2011;52(1):55-9.

278. Walls T, Hawrami K, Ushiro-Lumb I, Shingadia D, Saha V, Shankar AG. Adenovirus infection after pediatric bone marrow transplantation: is treatment always necessary? Clin Infect Dis. 2005;40(9):1244-9.

279. Lion T, Kosulin K, Landlinger C, Rauch M, Preuner S, Jugovic $\mathrm{D}$, et al. Monitoring of adenovirus load in stool by real-time PCR permits early detection of impending invasive infection in patients after allogeneic stem cell transplantation. Leukemia. 2010;24(4):706-14

280. Schilham MW, Claas EC, van Zaane W, Heemskerk B, Vossen JM, Lankester AC, et al. High levels of adenovirus DNA in serum correlate with fatal outcome of adenovirus infection in children after allogeneic stem-cell transplantation. Clin Infect Dis. 2002;35(5):526-32.

281. Grimley MS, Marsh RA, Bleesing JJ, Mehta PA, Jodele SA, Myers $\mathrm{KM}$, et al. Cmx001 as therapy for severe adenovirus infections in immunocompromised pediatric patients: single experience in 5 patients. Biol Blood Marrow Transplant. 2012;18(2):S315.

282. Florescu DF, Pergam SA, Neely MN, Qiu F, Johnston C, Way S, et al. Safety and efficacy of CMX001 as salvage therapy for severe adenovirus infections in immunocompromised patients. Biol Blood Marrow Transplant. 2012;18(5):731-8.

283. Grimley MS, Chemaly RF, Englund JA, Kurtzberg J, Chittick G, Brundage TM, et al. Brincidofovir for asymptomatic adenovirus viremia in pediatric and adult allogeneic hematopoietic cell transplant recipients: a randomized placebo-controlled phase II trial. Biol Blood Marrow Transplant. 2017;23(3):512-21.

284. Caserta MT, Dewhurst S. Dazed and confused by HHV-6. Blood. 2011;117(19):5016-8.

285. Yamane A, Mori T, Suzuki S, Mihara A, Yamazaki R, Aisa Y, et al. Risk factors for developing human herpesvirus 6 (HHV-6) reactivation after allogeneic hematopoietic stem cell transplantation and its association with central nervous system disorders. Biol Blood Marrow Transplant. 2007;13(1):100-6.

286. Olson AL, Dahi PB, Zheng J, Devlin SM, Lubin M, Gonzales AM, et al. Frequent human herpesvirus-6 viremia but low incidence of encephalitis in double-unit cord blood recipients transplanted without antithymocyte globulin. Biol Blood Marrow Transplant. 2014;20(6):787-93.

287. Zerr DM, Boeckh M, Delaney C, Martin PJ, Xie H, Adler AL, et al. HHV-6 reactivation and associated sequelae after hematopoietic cell transplantation. Biol Blood Marrow Transplant. 2012;18(11):1700-8.

288. Zerr DM, Fann JR, Breiger D, Boeckh M, Adler AL, Xie H, et al. HHV-6 reactivation and its effect on delirium and cognitive functioning in hematopoietic cell transplantation recipients. Blood. 2011;117(19):5243-9.

289. Hill JA, Koo S, Guzman Suarez BB, Ho VT, Cutler C, Koreth J, et al. Cord-blood hematopoietic stem cell transplant confers an increased risk for human Herpesvirus-6-associated acute limbic encephalitis: a cohort analysis. Biol Blood Marrow Transplant. 2012;18(11):1638-48.

290. Betts BC, Young JA, Ustun C, Cao Q, Weisdorf DJ. Human herpesvirus 6 infection after hematopoietic cell transplantation: is routine surveillance necessary? Biol Blood Marrow Transplant. 2011;17(10):1562-8.

291. Ogata M, Satou T, Kawano R, Goto K, Ikewaki J, Kohno K, et al. Plasma HHV-6 viral load-guided preemptive therapy against HHV-6 encephalopathy after allogeneic stem cell transplantation: a prospective evaluation. Bone Marrow Transplant. 2008;41(3):279-85

292. Ishiyama K, Katagiri T, Hoshino T, Yoshida T, Yamaguchi M, Nakao S. Preemptive therapy of human herpesvirus- 6 encephalitis 
with foscarnet sodium for high-risk patients after hematopoietic SCT. Bone Marrow Transplant. 2011;46(6):863-9.

293. Milano F, Campbell AP, Guthrie KA, Kuypers J, Englund JA, Corey L, et al. Human rhinovirus and coronavirus detection among allogeneic hematopoietic stem cell transplantation recipients. Blood. 2010;115(10):2088-94.

294. Campbell AP, Chien JW, Kuypers J, Englund JA, Wald A, Guthrie $\mathrm{KA}$, et al. Respiratory virus pneumonia after hematopoietic cell transplantation (HCT): associations between viral load in bronchoalveolar lavage samples, viral RNA detection in serum samples, and clinical outcomes of HCT. J Infect Dis. 2010;201(9):1404-13.

295. Seo S, Renaud C, Kuypers JM, Chiu CY, Huang ML, Samayoa E, et al. Idiopathic pneumonia syndrome after hematopoietic cell transplantation: evidence of occult infectious etiologies. Blood. 2015;125(24):3789-97.

296. Waghmare A, Pergam SA, Jerome KR, Englund JA, Boeckh M, Kuypers J. Clinical disease due to enterovirus D68 in adult hematologic malignancy patients and hematopoietic cell transplant recipients. Blood. 2015;125(11):1724-9.

297. Dokos C, Masjosthusmann K, Rellensmann G, Werner C, SchulerLuttmann S, Muller KM, et al. Fatal human metapneumovirus infection following allogeneic hematopoietic stem cell transplantation. Transpl Infect Dis. 2013;15(3):E97-E101.

298. Englund JA, Boeckh M, Kuypers J, Nichols WG, Hackman RC, Morrow RA, et al. Brief communication: fatal human metapneumovirus infection in stem-cell transplant recipients. Ann Int Med. 2006;144(5):344-9.

299. Schenk T, Strahm B, Kontny U, Hufnagel M, Neumann-Haefelin D, Falcone V. Disseminated bocavirus infection after stem cell transplant. Emerg Infect Dis. 2007;13(9):1425-7.

300. Kuypers J, Campbell AP, Guthrie KA, Wright NL, Englund JA, Corey $\mathrm{L}$, et al. WU and KI polyomaviruses in respiratory samples from allogeneic hematopoietic cell transplant recipients. Emerg Infect Dis. 2012;18(10):1580-8

301. Perfect JR, Cox GM, Lee JY, Kauffman CA, de Repentigny L, Chapman SW, et al. The impact of culture isolation of aspergillus species: a hospital-based survey of aspergillosis. Clin Infect Dis 2001;33(11):1824-33.

302. Wald A, Leisenring W, van Burik JA, Bowden RA. Epidemiology of aspergillus infections in a large cohort of patients undergoing bone marrow transplantation. J Infect Dis. 1997;175(6):1459-66.

303. Tarrand JJ, Lichterfeld M, Warraich I, Luna M, Han XY, May GS, et al. Diagnosis of invasive septate mold infections. A correlation of microbiological culture and histologic or cytologic examination. Am J Clin Pathol. 2003;119(6):854-8.

304. Cornely OA. Galactomannan testing during mold-active prophylaxis. Clin Infect Dis. 2014;59(12):1703-4.

305. Duarte RF, Sanchez-Ortega I, Cuesta I, Arnan M, Patino B, Fernandez de Sevilla A, et al. Serum galactomannan-based early detection of invasive aspergillosis in hematology patients receiving effective antimold prophylaxis. Clin Infect Dis. 2014;59(12):1696-702.

306. Affolter K, Tamm M, Jahn K, Halter J, Passweg J, Hirsch HH, et al. Galactomannan in bronchoalveolar lavage for diagnosing invasive fungal disease. Am J Resp Crit Care Med. 2014;190(3):309-17.

307. Safdar A, Singhal S, Mehta J. Clinical significance of nonCandida fungal blood isolation in patients undergoing high-risk allogeneic hematopoietic stem cell transplantation (1993-2001). Cancer. 2004;100(11):2456-61.

308. Choi SM, Xie H, Campbell AP, Kuypers J, Leisenring W, Boudreault AA, et al. Influenza viral RNA detection in blood as a marker to predict disease severity in hematopoietic cell transplant recipients. J Infect Dis. 2012;206(12):1872-7.

309. El Chaer F, Shah DP, Chemaly RF. How I treat resistant cytomegalovirus infection in hematopoietic cell transplantation recipients. Blood. 2016;128(23):2624-36.

310. Chou S. Approach to drug-resistant cytomegalovirus in transplant recipients. Curr Opin Infect Dis. 2015;28(4):293-9.

311. Hakki M, Chou S. The biology of cytomegalovirus drug resistance. Curr Opin Infect Dis. 2011;24(6):605-11.

312. Iioka F, Sada R, Maesako Y, Nakamura F, Ohno H. Outbreak of pandemic 2009 influenza a/H1N1 infection in the hematology ward: fatal clinical outcome of hematopoietic stem cell transplant recipients and emergence of the $\mathrm{H} 275 \mathrm{Y}$ neuraminidase mutation. Int J Hematol. 2012;96(3):364-9.

313. Renaud C, Pergam SA, Polyak C, Jain R, Kuypers J, Englund JA, et al. Early emergence of an $\mathrm{H} 275 \mathrm{Y}$ mutation in a hematopoietic cell transplant recipient treated with intravenous peramivir. Transpl Infect Dis. 2010;12(6):513-7.

314. Koo S, Bryar JM, Baden LR, Marty FM. Prognostic features of galactomannan antigenemia in galactomannan-positive invasive aspergillosis. J Clin Microbiol. 2010;48(4):1255-60.

315. Bergeron A, Porcher R, Menotti J, Poirot JL, Chagnon K, Vekhoff A, et al. Prospective evaluation of clinical and biological markers to predict the outcome of invasive pulmonary aspergillosis in hematological patients. J Clin Microbiol. 2012;50(3):823-30. 